\title{
The Virtuous Circle of Facts and Values in the New Western History
}

\author{
Gerry Kearns
}

Department of Geography, University of Cambridge, Cambridge, UK

\begin{abstract}
The relations between facts and values in the writing of historical geography need to be mutual and reinforcing. I explore this point by examining the work of a group of historians who have foregrounded the relations between facts and values. These New Western Historians take up themes such as social justice, regionalism, and environmentalism that have been central to the concerns of historical geographers, but they are more explicit than many historical geographers about both the political motivations behind the questions they ask and their choice of subjects to study. I consider the work of two historians, William Cronon and Donald Worster, who have made environmentalism the core of their historical writing, and two others, Richard White and Patricia Limerick, for whom questions of social justice inform historical interpretation. I conclude by exploring how attention to the interplay between facts and values might rekindle the utopian dimension of explicitly political historical geographies. Key Words: environmentalism, New Western History, social justice.
\end{abstract}

$\mathrm{T}$ he New Western History is a recent development that has garnered a wide audience for academic history by reexamining the crucial importance of the West to the political identity of the U.S. Under its inspiration, public exhibitions such as the Smithsonian's "The West as America" (Washington, DC, 1991), have questioned the central myth of the frontier as the place where civilization overcame savagery. This exhibition drove one Senator to bewail the Smithsonian's sponsorship of "perverted history." As Hughes (1994:161) remarked, "[s]tarting with Daniel Boorstin, the former Librarian of Congress, a whole crowd of politicos and right-wing columnists put on their boots and started kicking."

The central myth the exhibition questioned is inherently historical and geographical. It finds, as a source of the values and energy of the U.S., the process of colonization, whereby so-called "empty" space was gradually incorporated into the new republic. The "New Western History" (so termed by historian Patricia Limerick) accuses the mythmakers of downplaying environmental destruction, injustices to native peoples, and the race, class, and gender conflicts at the heart of the imperialist process of taking the land for the new, big country. To point toward how a new historical geography of the West might attend to a new series of political agendas arising out of the New
Western History, this paper examines the work of contemporary historians William Cronon, Donald Worster, Richard White, and Limerick.

The New Western History takes up issues that are major concerns of human geography, such as regionalism (Morris 1994; Thrift 1994), environmentalism (Williams 1994), and social justice (Smith 1994; Harvey 1996). These issues, then, are not new to human geography, or even to work on the historical geography of the U.S. Carl Sauer (1956) posed questions about the environmental destruction entailed by the industrial civilization that displaced Native American peoples from most of the continent. Richard Jackson (1981) has described the politics of land-use regulation. Donald Meinig $(1986,1993)$ has put the creation of regional diversity and its political implications at the core of his account of the shaping of North America and, furthermore, has not shrunk from describing the violent taking of the land as "imperialism." The New Western History also coalesces with some of the most interesting recent historical-geographical scholarship on North America, such as Nostrand (1992) on the U.S.Mexico borderlands and Wishart (1994) on the fate of the native peoples of Nebraska. A special issue of Ecumene (5[1], 1998) is devoted to the discussion of some of the relations between geography and the New Western History. At least one of the historians I discuss has engaged in debate 
with geographers. In the pages of Antipode, William Cronon has been attacked for being insufficiently marxist, while in the Journal of Historical Geography, he has been taken to task as insufficiently postmodernist. ${ }^{1}$ These two sets of criticisms focus in rather different ways on the question of the relations between facts and values that is at the heart of this paper. Yet there is something distinctive about the explicitly political nature of the historical agenda in the New Western History that has rarely been confronted in human geography. Geographers have been more willing to note the inevitability of personal bias and interest in the selection of subjects for study (Wishart 1997) than to subject their substantive, theoretical, and methodological choices to explicitly political or moral review.

The New Western History takes cognizance of the broadening horizons of social history as the latter engages with under-researched areas such as race and gender. These topics have, in large part, forced their way onto the academic agenda by virtue of the political visibility and selfconfidence of the new social movements that campaigned on behalf of their political salience in the 1960s and 1970s. The supposed value neutrality of historical scholarship has been fatally wounded by the development of social history engagé (Novick 1988; Nash et al. 1997), opening up the prospect of two-way traffic between political and historical scholarship (Scott 1988).

Geographers have much to learn from debates within history, and historical geographers have certainly kept abreast of the flourishing field of social history. Race and gender, for example, are topics to which Jeanne Kay has previously drawn the attention of historical geographers (1989, 1990, 1991). Yet when social historians explicitly address the study of the past to the concerns of the present, few historical geographers have followed with enthusiasm. In the New Western History, the values of historians past and present become an explicit part of the study. Because a mythology of the West is such an important part of the self-consciousness of the people of the U.S., this questioning of values has been contentious.

\section{Making the Circle Virtuous}

The frontier has been the central feature of the historiographical and mythological connection between landscape and identity in the U.S. In
Gunfighter Nation, Slotkin charts the continual reworking of the frontier myth in American politics and culture during this century. According to Slotkin, the prevailing version of the frontier thesis has not been that of Frederick Jackson Turner, but of U.S. President Theodore Roosevelt. ${ }^{2}$ While Turner stressed the importance of democratic processes in frontier farming communities, Roosevelt emphasized the earlier stage of the hunter securing space against "savagery." It is Roosevelt's account of the origin of truly American values that has held sway in the political culture of the U.S.: a legacy of conquest, race-war, and colonialism. Slotkin writes: "[w]hile Turner locates the crucial dynamism in a democratic collectivity, Roosevelt locates it in a successive class of heroes emerging from the strife of races to earn a neo-aristocratic right to rule" (1992:35). There are, then, different values and conceptions of the good polity, and different stories are available to support them. Slotkin's analysis highlights these tangled but important connections between description and prescription, between is and ought; his work thus raises the complex question of the place of values in scholarly inquiry.

Most scholars today would agree that theoretical categories are imbued with normative concerns. My interest is in making the circle between facts and values a virtuous one. In other words, what we learn about the world should inform our choice of appropriate political and moral stances. Beyond the most basic of commitments, moral and political questions frequently rest on certain claims about how the world (or society) works. Similarly, we need to set up theoretical categories so that we can draw ethically relevant conclusions from our studies. As Hirst (1990) has argued, blanket charges of relativism or objectivism can help us little here, for neither position is defensible or operationalizable. Where two accounts of the same aspect of social reality are in empirical contradiction, it will not do to defend their incompatibility on the grounds of political or theoretical pluralism, nor will it do to resolve the contradiction by appealing to one's affinity with the theoretical or empirical position of either writer of those accounts. Doing so places political and theoretical concerns beyond empirical embarrassment. Unless our politics and theory are vulnerable when they engage with the empirical world, they can have little purchase on that world. The relativist might claim that empirical work cannot decide moral issues, and thus a 
plurality of political and theoretical positions must be allowed. Yet to claim that empirical work has nothing to contribute to the evaluation of political strategy is to sever the link between utopia and reality in a way that is politically dangerous and contradicted by the evident embeddedness of all political movements, including new social movements. That embeddedness should be a matter of reflection, not denial. On the other hand, for the objectivist to suggest that one's moral outlook should not dictate one's substantive work is also a dogmatic evasion of the dialectical interplay with which we are concerned here. I agree that empirical work cannot be judged on the basis of the political or moral sign under which it has been written. Something is not to be judged as true or false simply because we agree or disagree with the political spin the writer places upon the study or even with the spin which, in a spirit of "hermeneutical suspicion" (Jones 1988:192), we imagine the writer incites us to place upon the study. It would, however, be impossible to sustain the claim that intellectual agendas are not shaped by theoretical preconceptions. There is a middle ground between objectivism and relativism where facts and values meet, mingle, and mutually reinforce or contradict one another. We need to negotiate the middle ground, and it is here that the New Western History offers some instructive examples of a virtuous circle of facts and figures (see Figure 1).

\section{The Vanguard}

In this essay, I examine the relations between normative and empirical concerns in the work of perhaps the four most prominent of the New Western Historians, "the vanguard" (Shoemaker 1996:10): Cronon, Worster, White, and Limerick. By explicating the moral concerns of their work, I intend to further explain how their narratives are structured and thus open a critique that shuttles between facts and values, examining their necessary interdependence. The vanguard New Western Historians, by engaging with the political purposes of environmental history, exemplify the interdependence between facts and values in ways that are directly relevant to geography.

Each of these historians is concerned with environmental history in one form or another. Cronon and Worster may be paired as concerned with the politics of nature, while White and Limerick are both concerned with the nature of politics itself. I begin my analysis by examining

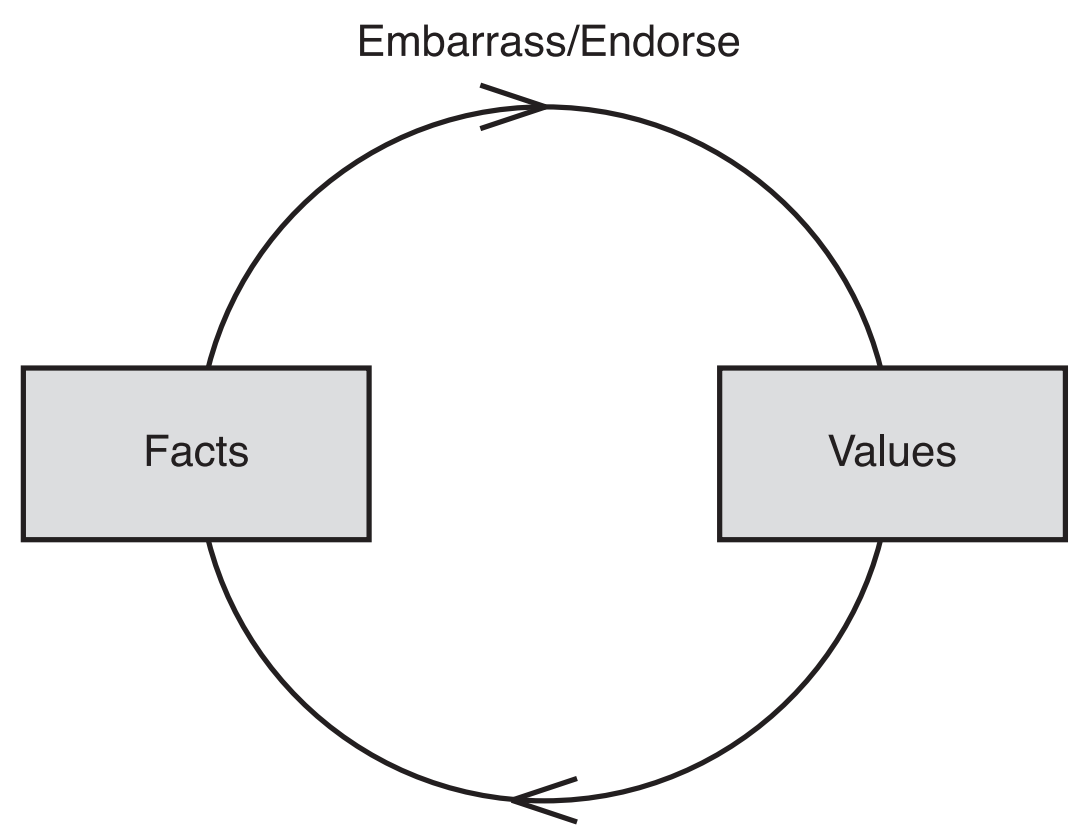

\section{Prioritize/Relegate}

Figure 1. The virtuous circle of facts and values. 
Cronon's differences with marxism, showing that divergent political concerns produce narratives with contrasting emphases. Marx's labor theory of value is normative in much the same way as Cronon's natural theory of value. Both embody empirical claims about the world, which in turn inform political choices. There are both empirical and political contrasts between Cronon and Marx. I am unwilling to dismiss Cronon as "ideological" and "wrong" simply because he is nonmarxist and thus "unscientific." I am also denying myself the comfort of simply celebrating the diversity of perspectives and stories. I argue that there are real differences of substance between the explanations that Cronon and Marx offer of the central dynamic of the colonial American economy. There are conflicting factual claims in their work that I will highlight but not claim to resolve.

I then turn to the conceptions of nature, science, and capitalism in the work of Worster, who is likewise concerned to establish his distance from marxism. I argue that his work is based on an unhelpful demonization of technology and a poorly explored vision of an alternative plausible present that we might conceivably inhabit. Again, I argue that there are both empirical and political claims at stake here and that we can meaningfully examine their interrelations.

Although, like Cronon and Worster, White and Limerick have written what might be termed environmental histories, their political concerns are less well defined as "green." Over time, White has become more explicitly concerned with questions of justice, while Limerick has increasingly focused on issues of regionalism and citizenship. White is acutely aware of the dialectic between facts and values, although in drawing attention to the provisional nature of the first and the multiplicity of the second, he is keen to avoid subordinating his empirical studies to the advocacy of any particular political position. Nevertheless, there is some merit in making the interconnections between facts and values a central feature in evaluating his work. His use of the metaphor of the "middle ground" invites this sort of framing of his exemplary narratives.

Where White is reticent, or at best guarded, about making specific connections between normative and empirical concerns, Limerick is clear and unambiguous. She wants both to sustain a distinct regional consciousness in the Southwest
U.S. and to claim for it a heightened awareness of the multiple claims to citizenship that the history of the region allows its diverse residents. This attention to the specificities of a particular region means that, for her, the West is most definitely a place rather than a process. In this, Limerick stands apart from the way Cronon treats the West. For Cronon, the West is a term to describe the incorporation of new territories into the emerging federal U.S. The claims of process treat the whole of the U.S. as a relevant, if changing, spatial entity. In this way, Cronon can even present the study of colonial New England as part of the same frontier story. ${ }^{3}$ For Limerick, as we will see below, this residual frontierism in Cronon bespeaks a geographical bias that treats American history as having one privileged trajectory, that from the east coast to the west. Instead, she claims only to be able to understand the multiculturalism of the Southwest U.S. by giving equal attention to Hispanic movements from the south and Native American displacements to the north, as well as to the traditional frontier movement from the east. In her attention to the Southwest as a distinctive place, she is particularly interested in the ways that engaged art can both express historical lessons and enliven regional consciousness. A concept of citizenship serves as a yardstick, allowing these lessons to be drawn in her own historical writing.

\section{Norms and Utopias}

Finally, I conclude by connecting the world of facts and values around the realms of norms and utopias. The connections across this pair of polarities inflect each other. We judge the past because we think it helps us to make the case that things might be different in the present. There would be no point judging the past were the course of history inevitable, fully determined, or located only in the past. Thus there is a connection between a belief in plausible worlds for the future and the exploration of counterfactuals in history. This is the form that historical lessons often take. Furthermore, our belief in possible alternative presents and futures informs our political commitments and attendant strategies (Hawthorn 1991). Yet such strategic thinking rests upon the feasibility of the alternatives we propose. Historical work is one way of exploring questions of feasibility. Because we think we understand why various options were closed 
down in the past, we achieve some sense of the difficulties that might attend their pursuit in the present. These are not the only ways that political thought can be advanced, but they remain useful ones. Stories about space, environment, and regions are central to many aspects of political identity and manifest destiny-which is to say that geographical imaginations shape political ones. This is a dialectic to which the New Western History directs our attention, and it is quite proper that we should attend to it.

\section{Theories of Value}

William Cronon is an environmental historian with strong connections to geography. Among other things, he holds a joint appointment in history, geography, and environmental studies at the University of Wisconsin-Madison and is on the editorial board of the Journal of Historical Geography. His two monographs, Changes in the Land and Nature's Metropolis, concern, respectively, the transformation of the environments of colonial New England and of the hinterland of nineteenth-century Chicago. Both books are concerned with the frontier process that has been so important to the U.S. experience. He has written extensively on environmentalism, conservation, and the idea of the West as a process rather than exclusively a place.

\section{The Commodification of Nature}

In all sorts of ways, Cronon's work displays a friendly respect for marxist scholarship. Indeed, many of his central categories sound very marxist: capital, exploitation, value, and commodity, to name a few. Changes in the Land is, among other things, an account of primitive accumulation in New England. Nature's Metropolis is, again among many other things, an examination of the cultural consequences of the commodification of nature. I want to begin, however, by establishing as irreducible and legitimate the different strategies between Cronon and Marx, after which I will explore the terms on which the two frameworks may be usefully brought to engage one another. Marx's politics aimed at the liberation of labor, whereas Cronon develops a politics based on the central importance of nature. Marx subscribed to a labor theory of value, whereas Cronon is committed to a natural theory of value.

For Cronon, people's relations with nature are dramatically reorganized through commodification:

The net result [of the commodification of nature] was to redefine the resources of the Alaskan landscape, pushing them beyond the needs of local subsistence into the realm of the market, where any good could be transformed into any other. At the same time the act of economic consumption came to be increasingly separated from the place of ecological production, distancing people from the consequences of their own acts and desires. A kind of alienation from nature was the inevitable result (1992b:39).

It is this alienation from nature that allows people to consume nature without paying any heed to environmental consequences. For Cronon, this is a pressing concern: "[1]ike other environmentalists, I am troubled by the many ways in which people alienate themselves from the natural world on which their lives depend" (1994a:169). Such a reading of alienation is related to but not quite the same as that of Marx, who described how the commodification of labor power alienated workers from the products of their labors, which now confronted them as autonomous commodities owned by others:

[T] he worker is related to the product of his labor as to an alien object. ... The worker places his life in the object [the commodity]; but now it [his life] no longer belongs to him, but to the object. ... The externalization of the worker in his product means not only that his labor becomes an object, an external existence, but that it exists outside him, independently of him and alien to him, and begins to confront him as an autonomous power; ... the life ... bestowed on the object confronts him as hostile and alien (1975 [1844]:324).

For Marx, capital is a social relation of production rather than a physical factor of production. Given a social arrangement where the means of production are privately owned as property by capitalists, while human work to produce goods is done by the propertyless, capital is the wherewithal for employing wage labor. Because the commodities the laborer produces belong to the capitalist, the process of production not only results in the alienation of the worker; it also reproduces the social relations of the propertied and the propertyless: 
Since the process of production is also the process of the consumption of labor-power by the capitalist, the worker's product is not only constantly converted into commodities, but also into capital, i.e., into value that sucks up the worker's value-creating power, means of subsistence that actually purchase human beings, and means of production that employ the people who are doing the producing. Therefore the worker himself constantly produces objective wealth, in the form of capital, an alien power that dominates and exploits him; and the capitalist just as constantly produces labor-power, in the form of a subjective source of wealth which is abstract, exists merely in the physical body of the worker, and is separated from its own means of objectification and realization; in short, the capitalist produces the worker as a wage-laborer (1976[1867]:716).

Furthermore, for Marx, "value" is the form of worth of a commodity in relation to other commodities, what it can be exchanged for in monetary terms. This is in contrast to its "natural form," what it can be used for (1976[1867]:138). The difference between what the inputs to the production process can be exchanged for and what the outputs from the production process can be exchanged for is the value-added in production. This value added by work is the value of labor. It equals the wages paid to the worker (which are used to meet the worker's subsistence needs, to reproduce the worker's capacity for labor, also known as variable capital or the exchange value of labor power) plus the surplus value which accrues to the capitalist (pp. 320-29). Given a circumstance in which production rests upon capitalist relations, the source of value, then, is labor. This is what the value form, as opposed to the natural form, is measuring. The value of the material inputs to the production process, then, equals the labor embodied in their earlier production, the value of dead labor.

For Cronon, however, capital takes on a distinctly green hue. In Nature's Metropolis, he writes that Chicago's growth rested upon the exploitation of the natural abundance of the prairie. He concludes that: " $[\mathrm{m}]$ uch of the capital that made the city was nature's own" (1991:150-51). This, he tells us, is where value comes from. Cronon also remarks that, from an ecological point of view, Marx's relations of production might better be seen as "relations of consumption, since all human labor consumes ecosystemic energy flows in the process of performing physiological and mechanical work" (1990:1124; emphasis in original). Production, then, rests on a set of nonhu- man energies and resources that have value. Cronon concludes that we "have to assign a much larger role to nature in the creation of such use value" (1990:1125).

This belief shares similarities with but is different from Marx's formulation. In taking issue with Marx, Cronon is asserting one normative conception of value against another: alienation from nature, not alienation of labor; natural capital, not capital as dead labor; a natural theory of value, not a labor theory of value. Furthermore, Cronon is quite explicit about the need for history to articulate such normative concerns, suggesting that "[i]t is because we care about the consequences of action that narratives-unlike most natural processes - have beginnings, middles, and ends" and that "[t]he difference between beginning and end gives us our chance to extract a moral from the rhetorical landscape. Our narratives take changes in the land and situate them in stories whose endings become the lessons we wish to draw from those changes" (1992c:1370).

It is no real answer to Cronon simply to show that all the points he makes are recoverable within the orthodox marxist account, by, for example, arguing that using up the natural abundance of the prairie might be understood through the concept of differential rent and its determination by soil fertility (Marx 1974a[1894]:650-68). Nor is it enough to show that Marx drew a distinction between value and use value (1976[1867]:163-68) that precisely captures Cronon's distinction between labor and nature. Cronon and Marx provide parallel though compatible accounts based on parallel but irreducible value orientations. Marx was concerned with a utopia in which the control of labor power would be taken from the capitalist and returned to the worker: "[l] et us . . . imagine, for a change, an association of free men, working with the means of production held in common, and expending their many different forms of labor-power in full self-awareness as one single social labor force" (1976[1867]:171). It is this vision, the possibility of which Marx saw as immanent in contemporary social trends (and thus as a plausible utopia), that shaped Marx's indictment of the capitalist relations of production under which his laboring contemporaries were starved, broken, humiliated, and reduced. ${ }^{4}$

Cronon is likewise focused upon a better world, one where ecological sustainability and respect for all life, human and nonhuman, is paramount. His vision rests upon a sense of place, a commit- 
ment to the local world as our home, and a recognition that we are engaged in a continuous dialogue with the earth we live in: "[h] owever we come to our love of the land ... the important thing is that we learn to care for it as more than an abstraction.... The great challenge we face is to do right by the land we have made our own" (1990-1991:103). To draw attention to the imperative to respect nature, Cronon organizes his work around a theory that valorizes nature in the present.

Cronon and Marx thus offer two different analyses of society's central problems, different agendas for change, and different theories of value. The natural theory of value in Cronon's work demands an intellectual engagement with society's central problems and not just the assertion of a purer marxist alternative (pace Merchant 1994; Pudup 1994; Page and Walker 1994; Saunders and Marston 1994, see below). In other words, even if the labor theory of value can save the phenomena Cronon highlights, it does not follow that marxist theory is thereby vindicated. Given the irreducibly normative content to what we find interesting about the world, it should be clear that I cannot agree with those who bemoan the fact that Nature's Metropolis does "not quite add up to a general analysis of the spatial and ecological effects of nineteenth-century capitalism in a vast, inviting tract of the New World where, through much of a century, capitalism held a particular sway" (Harris 1994:123). The dream of a politique totale is as chimerical as that of an histoire totale. I cannot agree with those who assert the theoretical priority of issues of labor over those of ecology by invoking the fact that "[f] or Marx, labor and nature are 'identical expressions' such that the exploitation of labor (human property) is inseparable from the exploitation of nature" (Saunders and Marston 1994:127). Merchant's observations are more on target: "[b]y bracketing the relations of production, Cronon's critique of the market is limited to its ecological costs.... [T] he ultimate outcome of the bracketing of the relations of production ... is an embracement of green capitalism. The main conclusion that we as readers are left to draw is an implied admonition that the commodification of nature must somehow be made environmentally sound" (Merchant 1994:137). On grounds of both political strategy and empirical adequacy, there may be reasons to contest the particular focus of Nature's Metropolis, but it can hardly be done in the name of some other all-encompassing position. ${ }^{5}$ It is difficult to avoid Cronon's exasperation:

All narratives are partial. All succeed by ignoring vast stretches of reality. All distort the world with their selectivity. There are no genuinely totalizing narratives, just narratives that deceive their readers and listeners into believing they are such (1994a:172).

Nor can we avoid his claim that you might easily substitute "theory" for "narrative" in the above quotation. ${ }^{6}$

\section{Marx and Cronon on Primitive Accumulation}

I recognize that the different normative concerns of Marx and Cronon frame different ways of looking at the world. Different things are valued and brought into focus. Here I turn briefly to the engagement with marxism in Cronon's earlier Changes in the Land. One thing this book offers is an account of ecological transformations of New England by European farmers. Here Cronon argues that "economic and ecological imperialisms reinforced each other" (1983:162), resulting in environmental degradation. As the New England farming economy moved from a seventeenthcentury subsistence base to a market-driven nineteenth-century system in which resources were treated as commodities rather than as providing subsistence (p. 76), the effects on nature became more marked. These, in turn, reacted upon the economy: "[e]cological pressures brought on by overgrazing and inadequate forage reinforced economic incentives flowing more directly from market demand: together, the two impelled colonial movement onto new lands" (p. 162). This might appear, once again, to be little more than Cronon insisting on the importance of ecology to supplement alternative accounts that focus simply on labor. At points, Cronon suggests as much:

[n] ot only colonial agriculture, but lumbering and the fur trade as well, were able to ignore the problem of continuous yield because of the temporary gift of nature which fueled their continuous expansion. When that gift was finally exhausted, ecosystems and economies alike were forced into new relationships: expansion could not continue indefinitely (p. 169).

Yet Cronon has an economic explanation for this attitude toward nature. He argues that New En- 
gland was an economy in which labor and capital were scarce and land was substituted for both: "[1] and in New England became for the colonists a form of capital, a thing consumed for the express purpose of creating augmented wealth" (p. 169).

It appears here that attitudes toward nature are being explained by way of a neoclassical account of the economy in terms of the return to immobile, inconvertible factors of production. Yet, within such a neoclassical framework, if capital was scarce, why did not the rate of interest rise to the point at which funds would have left the European economy and been invested in New England? If labor was scarce, why did not wages at the frontier swell to the point where labor would have been lured away from European town and country? The answer is, of course, that perfect mobility of factors of production is a highly unrealistic assumption for colonial New England. This recognition highlights the institutional and material setting of production that rarely surfaces in neoclassical accounts. Even within that neoclassical framework, capital and labor scarcity might as easily be explained in terms of the low price of land that encouraged an extensive system of production. But that price, in turn, reflected a political situation in which resources could be taken from Native Americans at little cost to the settlers themselves, returning us once again to the material and institutional context. The costs of setting up this sort of farming economy were borne in large part by the government as a military expenditure. Writing of the settling of the Ohio Valley, Aron notes that between 1790 and 1796, eighty percent of the federal budget of the U.S. was spent on war with the Native Americans of Ohio (1994:139).

In contrast to neoclassical economics, Marx was very interested in the institutional setting of what he termed capitalist relations of production. Instead of factors of production, he directs attention toward the political and social preconditions of the appearance of "things" as factors. It is in this sense that one may speak of Cronon's Changes in the Land as being about primitive accumulation-the process whereby these preconditions are realized. Without them, independent, subsistence farming is the more likely arrangement. Marx described how Edward Wakefield's studies of colonization led Wakefield to an appreciation of the social prerequisites for the existence of capital:

Wakefield discovered that, in the colonies, property in money, means of subsistence, machines and other means of production does not as yet stamp a man as a capitalist if the essential complement to these things is missing: the wage-laborer, the other man, who is compelled to sell himself of his own free will. He discovered that capital is not a thing, but a social relation between persons which is mediated through things. A Mr. Peel, he complains, took with him from England to the Swan River district of Western Australia means of subsistence and of production to the amount of $£ 50,000$. This Mr. Peel even had the foresight to bring besides, 3,000 persons of the working class, men, women and children. Once he arrived at his destination, "Mr. Peel was left without a servant to make his bed or fetch him water from the river." Unhappy Mr. Peel, who provided for everything except the export of English relations of production to Swan River! (1976[1867]:932-33).

Marx went on to offer an explanation of these colonial conditions different from that of Cronon:

We have seen that the expropriation of the mass of the people from the soil forms the basis of the capitalist mode of production. The essence of a free colony, on the contrary, consists in this, that the bulk of the soil is still public property, and every settler on it can therefore turn part of it into his public property and his individual means of production, without preventing later settlers from performing the same operation. This is the secret both of the prosperity of the colonies and of their cancerous affliction-their resistance to the establishment of capital (1976[1867]:934).

This, it seems to me, is a more adequate account than one which takes the relative scarcity of the different factors of production for granted. It offers a description of how such a state of affairs arose and, moreover, highlights the institutional and geographical arrangements under which matters would soon fall out differently. If Cronon wanted to offer a neoclassical explanation of attitudes to nature, he would have done better to focus on the price of land than the scarcity of capital. But if he wanted to examine the links between ecological and economic imperialism, then Marx's emphasis on capital as a social relation rather than a factor of production is more adequate than an emphasis on scarcity of land or capital.

\section{What Cronon Adds to Marx}

Before I leave this discussion of the relations between green and marxist critiques of capitalism, I want to comment briefly on what Cronon adds to Marx's account. First, Cronon is correct 
to note that marxists pay relatively little attention to the feedbacks from nature to society. In fact, historical materialists generally display a disturbing lack of interest in the organization of the material basis of society, be it in terms of ecology, demography, or communications (Kearns 1984b:416). The precise consequences of this will vary from case to case, but in the case of colonial New England, a failure to recognize the extent to which the uses made of the land by early colonists proved unsustainable would indeed compromise any account of the dynamics of the agricultural economy. Second, Cronon is also correct to prise apart the effects of the proletarianization of labor and of the commodification of nature in his account of the expansionary dynamic of capitalism. Marx conflates the two in his analyses of agricultural capitalism in volume 1 of Capital (1976 [1867]:chs. 26-33). Cronon describes a transition from a subsistence to a capitalist economy in New England between the seventeenth and nineteenth centuries:

[m] ost early farmers owned their own land, hired few wage laborers, and produced mainly for their own use. Markets were hemmed in by municipal regulations, high transportation costs, and medieval notions of the just price. In none of these ways does it seem reasonable to describe colonial New England as "capitalist" (1983:76).

From the seventeenth century, resources began to be seen increasingly as commodities:

\begin{abstract}
Although an earlier English meaning of the word "commodity" had referred simply to articles which were "commodious" and hence useful to people ... that meaning was already becoming archaic by the seventeenth century. In its place was the commodity as an object of commerce, one by definition owned for the sole purpose of being traded away at a profit (p. 76).
\end{abstract}

Items such as fish, furs, and timber were increasingly seen as commodities,

valued not for the immediate utility they brought their possessors but for the price they would bring when exchanged at market. In trying to explain ecological changes related to these commodities, we can safely point to market demand as the key causal agent (p. 76).

It would appear that this market orientation is independent of the existence of generalized wage labor. In other words, capitalist forms of calculation and profit, and the production of commodities by commodities, can proceed on the basis of owner-occupiers and can have dramatic ecological consequences, even while the economy is not yet organized on the basis of universal wage labor. This view has implications for the account of agrarian capitalism in Capital. Marx's emphasis on the subordination of labor to capital led him to theorize the emergence of English agrarian capitalism primarily in terms of the emergence of agricultural wage labor during the seventeenth and eighteenth centuries. Yet, in terms of the production of commodities by commodities and the demonstrable effects that this had on patterns of land use, there is no need to tie the emergence of capitalist calculation in production to the availability of wage labor.

This theoretical point has important implications for empirical, historical accounts. There has been a tendency for marxist historians to illustrate Marx's claims about the development of agrarian capitalism rather than to consider the central assumptions on which his argument rested. In fact, in the history of English agriculture, there was indeed a separation, historically, between the widespread organization of farming as the production of commodities by means of commodities, and the emergence of wage labor as the primary form of work in agriculture. Empirically, the former did not always imply the latter. Tribe argues that:

Capitalism can be briefly summarized as a form of economy in which consumption is separated from production, enterprises are separated and in a state of competition, and the national economy is coordinated according to the profitability of the commodities sold by enterprises. ... In principle, then, the "capitalist farm" could be either a large farm in which a farmer supervises wage-laborers, or a family farm in which family labor is supervised by a household head: the absence of wage-labor does not mean that a farm is non-capitalist (1981:38).

Cronon's identification of the commodification of nature as the prelude to the transformation of nature by economic and ecological imperialism is a more satisfying explanation than one which saw the process of primitive accumulation as being primarily one involving the commodification of labor power. With time, the further development of the productive forces in agriculture is inconceivable without the exploitation of wage labor. Given private ownership of land, the pursuit of scale economies in the use of machinery and other expensive inputs requires a large agricultural proletariat. Given the technological arrangements of nineteenth-century agriculture, 
for example, a point would be reached in developing the land productivity of agriculture where wage labor would be an essential prerequisite. This land-intensive option becomes unavoidable once the supply of so-called "free" land is restricted or when land values rise for some other reason (for example, by reason of the competition for the locations most accessible to market).

In some ways, then, the labor theory of value and the natural theory of value imply not only different political projects but also different sets of empirical blindspots. When they are deployed in the explanation of essentially similar phenomena (in this case, the ecological consequences of land-use practices in New England), we can evaluate the effects of these empirical biases. Cronon's normative concerns look toward a better world where people forge a meaningful relationship with the place in which they live, allowing them to cherish its natural setting and thus sustain its natural value. The bête noire of his story of colonial New England, then, is the attitude of colonial settlers to the land which he sees as the result of its commodification. These normative concerns bring certain issues into focus and leaves others in the shadows. ${ }^{7}$ Certain facts are prioritized, and others are relegated. The crediblity of Cronon's vision of a better world must rest to some extent on the adequacy of his diagnosis of the causes of the environmental problems he describes. If things did not turn out the way he describes for the reasons he gives, then we might wonder whether they would get better if we worked for a society organized around the values he espouses. Cronon prioritizes the destruction of natural value, species variety, and numbers. For Cronon, commodification confounds the sustainability implicit in subsistence economies.

\section{Imperial Ecology and Capitalism}

Over the past two decades, Donald Worster has been one of the most influential environmental historians in North America. His studies in the history of environmental ideas have gained an academic and popular audience. His two main historical monographs have concerned the ecological disasters of the Dust Bowl and the extraction of the waters of the Colorado for the benefit of some of the people of California. Among the
New Western Historians, none has been more explicit about the normative basis of their categories than Worster. ${ }^{8}$

In the case of Worster, we can trace the full virtuous circle from facts to values and back again. Worster is opposed to the human domination of nature. He believes that being in harmony with nature would promote a natural egalitarianism and a form of social solidarity rooted in the recognition of ecological interdependence. This is the basis for his attack on the exploitation of nature that he finds in what he terms, following Wittfogel (1957), the hydraulic society of the Western U.S. By a hydraulic society, Worster means one in which the taming of rivers provides the central resource for agriculture and energy:

There is no freedom for nature itself, for natural rivers as free-flowing entities with their own integrity and order. .. . There is nothing harmonious, nothing picturesque about the western world that has developed beside the irrigation ditch. There is little peace or tidiness or care, little sense of a rooted community. There is no equitable sharing of prosperity $(1985: 4,5)$.

He distances himself quite explicitly from marxism. Criticizing Carey McWilliams's (1971) "standard leftist analysis" of the economy and society of California, in which McWilliams highlighted the inequality and exploitation intrinsic to a capitalist order, Worster writes that McWilliams:

[F]ailed to make room for nature, either as a historical actor or as a moral issue. In that respect, leftists were no different from capitalists, both standing for the conquest of the natural world, and their visions of the future tended to converge toward the same technological utopianism. . . . His Marxist-like logic tells McWilliams that private property, not the domination of nature, is the source of all abusive power, and in agriculture, he assumes, private property must mean private, concentrated landownership ... Put the new-fangled hydraulic society under socialism, he suggests. Make nature obey the dictates of collective ownership, and the West will be set right. Power will then belong to all the people, which is to say it will cease to be a social problem (1985:231, 232).

For Worster, such suggestions are a pipe dream, for domination over nature will always lead to the inequitable domination of some people over others, to ecological vandalism, and to a slight upon the integrity of nature. 
Table 1. Theories of Naturea

\begin{tabular}{lll}
\hline & \multicolumn{1}{c}{ Arcadian } & \multicolumn{1}{c}{ Imperial } \\
\hline Spirituality & Pagan & Judeo-Christian \\
Attitude to nature & Humble wonderment & Technological arrogance \\
Conception of natural order & $\begin{array}{l}\text { Unity in diversity, } \\
\text { organic synthesis }\end{array}$ & $\begin{array}{l}\text { Mechanism of detachable parts, } \\
\text { mechanical reductionism }\end{array}$ \\
Meaning of nature & Beauty, life & Productivity, resources \\
Route to understanding & Natural history & Laboratory science \\
Cultural forms & Naturalism, romanticism & Humanism, positivism \\
Practical implications & Conservation & Industrialization \\
Ecological yardstick & "Climax" stability & Trophic energy, efficiency \\
$\begin{array}{l}\text { Narrative form for } \\
\text { describing modernization } \\
\text { (after Cronon 1992c) }\end{array}$ & Tragedy & Progress \\
\hline
\end{tabular}

a after Worster 1977; Cronon 1992c.

\section{The Arcadian View of Nature}

Worster's analysis is a cultural critique of science and capitalism. On one hand, Worster criticizes what he terms an imperialist attitude to nature and, on the other, he rejects capitalism as a basis for organizing economic priorities. For Worster, the societies of Europe and North America are characterized by a fundamentally imperial attitude toward nature (see Table 1). Nature is seen as a mechanism to be adjusted for the shortterm productivity needs of society. The fullest development of this view of nature is about three hundred years old and provided the intellectual roots of industrialization. There is an older, more benign, view that Worster terms Arcadian. In contrast to Judeo-Christian societies that treat nature with technological arrogance, seeing the natural world as little more than a mechanical order, pagan, Arcadian views cultivate an attitude of humble wonderment in the face of the unity in diversity of our ecological home. For Arcadians, nature means beauty and life, best understood through natural history. It is not to be understood, as it is by imperialists, as little more than a set of resources to be mastered through laboratory science. Arcadians take a romantic rather than a positivistic view of nature and aim at stability and conservation rather than at industrialization and the maximum use of energy (as is said to characterize the imperialists). Cronon draws a helpful distinction between the narrative forms through which Arcadians and imperialists express their visions of nature. He detects tragedy in the Arcadian view, a falling from grace, and he notes the emphasis on progress in imperialist narratives. Worster dislikes imperialism with a vengeance: "we have had enough of imperialism. ... In this age of deadly mushroom clouds and other environmental poisons, I believe it is surely time to develop a gentler, more self-effacing ethic toward the earth" (1977:346). Alongside imperialism, the second criminal in the dock is capitalism, defined as business attitudes, "a core of values and assumptions," and "an enduring ethos" (1979:6).

For Worster, imperial ecology and capitalism were responsible for the Dust Bowl (see Figure 2). Both capitalism and imperialism promoted the idea that nature had no limits. America's economic culture "never recognized any limits nor restrained the appetite for gain" (1979:63), while Americans' "faith in the benignity of nature" (p. 27), their belief that humanity "is a sovereign creature, independent of the restraints that plague other species" (p. 94), and their expectation that technological fixes could restore any temporary loss of land productivity (p.179), together reinforced the idea of an irrepressible economy and a boundless natural bounty. But disasters such as the Dust Bowl should "challenge a society's capacity to think" and "require it to analyze and explain and learn from misfortune" (p. 25). Yet the U.S. proved immune to ecological education. Ameliorative government actions such as those begun in 1933 by the Farm Credit Administration (p. 124) and Agricultural Adjustment Administration (p. 155) froze landholding 


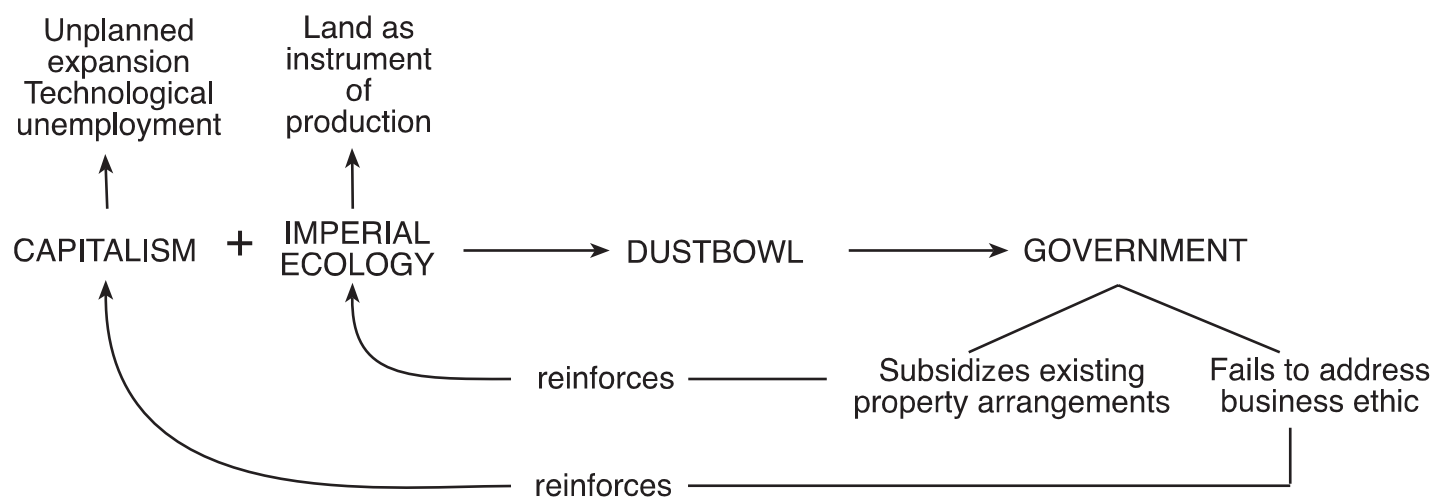

Figure 2. The Dust Bowl (after Worster 1979).

arrangements, preventing even that rearrangement the market might have induced (pp. 25, 163), while the Soil Conservation Service sustained the resumption of environmental vandalism (p. 229). At no point did the government "begin to touch the commercial mode of farming" (p. 196). A capitalist ethic continued to prevail.

\section{A Communitarian Vision}

In more recent work, Worster has moved beyond this attack on business values to articulate a communitarian vision of a decentralized anarchist utopia (although, as far as I am aware he has not discussed this specific political philosophy in any detail). This value orientation informs a normative conception of democracy and autonomy that presents big government and laissez faire as the twin evils sustaining the imperial view of nature. He has also subsequently introduced sharper ecological sensitivity into the picture, discussing both a pastoral mode of production, or "cowboy ecology" (1992a), and a hydraulic mode of production (1992b) in the western U.S. In the pastoral mode of production, only local control and entrenched traditions can solve the problem of overgrazing:

The safest strategy over the long run appears to be one that opens decisions about using the range to as many people as possible. The most stable systems of grazing have been those in which the experience, knowledge and moral pressure of a whole community guided the individual grazier (1992a:51).
Neither laissez faire nor remote central government succeeded in preventing overgrazing on the Great Plains in the 1880s. Worster's case is clear and is readily subject to consideration both as a political blueprint (can we get to anarchist communitarianism from here?) and as a plausible counterfactual (were nucleated Alpine-style villages a realistic option on the sparsely populated Great Plains?).

In his Dust Bowl, Worster scans the southern plains for alternative ways of making a living on the land. He believes that what is required is some sort of ideological vaccination against the blandishments of capitalist, modern society. Only when land ceases to be seen as a commodity, and only when community is identified in some strong sense with the land itself, can true ecological adaptation develop:

When both the identity of self and community become indistinguishable from that of the land and its fabric of life, adaptation follows almost instinctively.... This is genuine adaptation, and it implies much more than shallow managerial skill. It comes from having a sense of place, which is at once a perception of what makes a piece of land function as it does and a feeling of belonging to and sharing in its uniqueness (1979:164).

This is suggestive rather than persuasive, since instinctive adaptation remains unexplained. Nevertheless, the exploration of once-existing and perhaps even still-surviving alternatives is an important way of bringing empirical concerns to discussion of values. This is what Yeo recognized when he wrote that: 
From a conservative point of view, one uninterested in change or in history except as a ratification and celebration of the present, attempts are always being made to collapse "ways of life" into a single "society" or "system." And then the way is open to say that the ways we meet, define, multiply or divide needs, constitute a single "culture"-_our" way of life, the system. ... The function of so doing is to remove from view ownership, power, struggle, interests. It is to conceal alternative, latent potentials and achievements, in the interests of existing, manifest facts and ideologies. Above all, it is to devalue memory and collectivization in history. Competition and struggle involve loss and defeat as well as growth: presents involve running over unrealized but partly surviving pasts and temporarily blocked futures (1980:113).

In this sense, the most radical pages of Dust Bowl may be the brief remarks upon the farming successes of the Mennonites. Worster contrasts the Mennonites and moral puritanism, both of which he sees as forms of resistance to modern capitalism that promised to build new relations with the land in the hope of instinctive adaptation. He is impressed with the Mennonites, who: "[i]n their communalism, their stability, their careful husbandry, and their high degree of selfsufficiency . . . presented some alternative answers to the challenges of the Dust Bowl thirties" $(1979: 174)$. On the other hand:

Nurtured by itself, a moral rigidity toward booze and sexual freedom - and that was essentially all puritanism here meant-was not equivalent to a genuine indigenous cultural base. It contributed nothing to environmental adaptation, nothing to a sense of place. In fact, it worked to mask the extent to which those things were lacking (p. 178).

Yet many other religious groups also failed to establish viable farming communities. Worster would presumably not be comfortable with the observation that the Mennonites were simply better farmers than the rest (White 1991b:434), but these few brief pages do not really provide a causal explanation of how religious ideas, a genuine indigenous cultural base, and instinctive ecological adaptation are related. For Bogue, the crucial advantage of Mennonite communities was not a different attitude to the land but, instead, a strain of winter wheat they brought with them to the U.S. from Russia (Bogue 1994:307). Szasz and Szasz remark on the mutability of Mennonite institutions in the U.S., noting that, rather than a response to the physical environment, it was the more tolerant political and cultural envi- ronment that encouraged many Mennonites to forsake banding together in tight communities in favor of a more dispersed settlement pattern: "Although some branches of Mennonites retained the communal emphasis, the majority became individual farmers" (1994:374).

\section{Resisting the Hydraulic Society}

In his few pages on the Mennonites, Worster fails to deliver on his promise to draw persuasive lessons from the historical study of alternatives to modern capitalism. Neither does Worster begin to explain how resisting the modern age might be made attractive to Americans. Elsewhere he has promised that "[a] stable rural society in equilibrium with the processes of nature cannot allow much freedom or self-assertiveness to the individual" (1993b:66). He does not flinch from spelling out the full implications of properly recognized ecological constraints:

Of course, all those restraints put a ceiling on the amount of private wealth that any one person in the community can accumulate. They limit creativity. They make rural life conservative and hidebound. But they prevent most of the failures caused by misjudgment, egotism, ignorance, ambition, experimentation, excitement, and fantasy (p. 67).

Nevertheless, Worster's use of history to explore alternatives to imperial ecology is an intriguing way to connect facts and values. In a recent paper, Worster called for a history of adaptation to nature rather than of its technological conquest:

[I]f nothing else [it saves] us from gloom and excessive pessimism. We need new kinds of heroes, a new appreciation of nature's powers of recovery, and a new sense of purpose in this region-all of which means we need a new past, one with the struggle for adaptation as its main narrative, one that regards successful adaptation as a kind of heroism too (1992c:253).

It is in his account of the hydraulic society of the Great West (another conquest narrative) that Worster's political values are most prominent. Here he makes an explicit case that the drive to dominate nature inevitably entails dominating people (Harvey 1996). He employs Wittfogel's hydraulic civilization and Horkheimer and Adorno's instrumental reason to define a political economy of science in which decentralized communitarianism has no chance to survive, but yet 
stands out all the more starkly defined as the utopian alternative to technology gone mad and nature laid to waste. This thumbnail sketch does scant justice to the verve and panache of Rivers of Empire. Nevertheless, I want to highlight a few of the empirical and conceptual difficulties to which this particular normative framework gives rise.

First, the notion of ecological stability by which the hydraulic empire is found wanting is problematic. Worster notes the difference between EuroAmerican and Native American attitudes to nature, suggesting that the native peoples of the Plains might have delivered the following lesson to the early Euro-American settlers: "[f]irst control your numbers . . . then simplify your wants and see the earth as everybody's mother rather than as a piece of property to be divided by competing individuals" (1979:80). But Worster sees the ecological sustainability of Native American food demands as leaving so light an impress upon the land that it was almost as if they were not there at all. In a testy response to the claims of Pyne, who, he said, wanted "to reduce all environmental history, preindustrial and postindustrial alike, to a common pile of ashes" (1990b:1143), Worster is impatient with the claim that the American environment in the West had been substantially altered before the arrival of Euro-Americans: "Without bogging down in pedantic wrangles over definitions, we can say that before contact the native peoples were dwelling on a largely undomesticated continent, wild or nearly wild over much of its extent" (1993a:5). Unless the environment was at climax stability beforehand, the destructive impact of imperialism would be difficult to register. As WillemsBraun (1997) notes, this marginalizes native peoples by placing them at a traditional pole outside the challenges and possibilities of modernity, while also corralling them in village spaces detached from a pristine nature too easily presented as a freely available suite of resources upon which no prior claims have been made. But Walton is persuaded that Paiute Native Americans, at least in Owens Valley, California, were practicing irrigated agriculture (1992:14-15), and even if Pyne exaggerates the effects of fire, it seems easier to acknowledge the importance of fire than to dismiss it altogether. Worster's conclusion is questionable: "After several thousand years of [Native American] habitation, the [Great] valley's ecological order was still more or less intact" (1985:8). Worster himself has noted the difficulty ecologists now have with concepts of climax and equilibrium (1977:241, 1993b), but the importance of these concepts to Rivers of Empire is clear. Even if partly correct, Worster's suspicion that much of the attack on what he sees as ecological verities is motivated by a right-wing Social Darwinist backlash against conservation offers little security against the empirical arguments advanced.

The second problem with the analysis concerns the lack of any serious attention to resistance. Worster maintains that both localities and nature are crushed by the juggernaut of big business and big government. The only resistance he can envisage comes from Arcadian ecologists (subversive scientists and a modern, ecofriendly public). Yet something like his Arcadianism has been an enduring tradition in the American Southwest, one built on an appreciation of Native American myths and practices, in the tradition of Thoreau. This tradition, as Rudnik describes it, has been broadly feminist. It is a tradition that saw in the region:

[A] New World whose terrain, climate and indigenous peoples offered a model of ecological, spiritual and artistic integration to an alienated and decadent Western civilization. [These women's] perceptions were rooted in their ideal of a multiethnic democracy that recognized the long-ignored social, economic and cultural contributions of women, Hispanics and Indians to the life of the region and the nation (Rudnik 1987:10).

The apparent resistance of the land to imperialism echoed the resistance of women to patriarchy. There is a tradition of resistance that runs from Mary Austin to Patricia Limerick and that continues to nourish environmentalism and conservation, as Merchant has recently reminded Worster: "[T]he efforts of thousands of women were directly responsible for many of the country's most significant conservation achievements. Women writers on nature such as Isabella Bird, Mary Austin, and Rachel Carson have been among the most influential commentators on the American response to nature" (1990:1119).

Related to this failure to recognize feminist resistance to imperialism (leaving his romantic Arcadianism alone in the lists against capitalism) is a simplistic notion of the relations between big government and localities that underwrites a despairing politics, one that rejects all forms of government beyond mutual aid in the village. Worster thereby simplifies central government and ignores how local forces used it. These dia- 
lectical relations are, however, central to other work on the water politics of the western U.S. For example, Pisani draws attention to the diversity of water laws in the West throughout the second half of the nineteenth and well into the twentieth century. The significance of this diversity lies not in some antiquarian objection to generalization, but, rather, in the continuing extent of local autonomy in the face of widespread fears of monopoly and federal interference with property rights. Under these conditions, local control was preferred by many. Pisani concludes that:

At the state level, the diversity of western water laws was potent evidence of the power of localism. In fact, virtually all water law reforms were undertaken not in the name of rationality and bureaucratic order, but rather, because one group of water users sought dominance over another, or one community, region, or state sought to gain a competitive advantage over another (1992:335).

In trying to referee local conflicts, central government was drawn into and became a resource in those struggles. At least in the case of water policy, it did not roll over locality and variety in the name of instrumental reason or bureaucratic fiat.

Walton goes even further in raising problems for Worster's treatment of resistance. In a study of water use in Owens Valley, he notes how central government involvement in the conflict between locals and the city of Los Angeles legitimized resistance even as it asserted interference. In constructing a justice argument around resource use, the government deployed essentially contestable terms, circulating a rhetoric of intervention that could be appropriated as a rhetoric of resistance. Thus, Theodore Roosevelt promoted the "progressive" state by promising to use state power to drive the development of moral capitalism. As such, the water needs of the urban center of Los Angeles took priority in strictly utilitarian terms, but the Owens Valley citizens presented themselves as pioneers of moral capitalism in exactly these terms. They presented small-town society and agricultural smallholders as the very backbone of the moral economy. In ensuring obedience and coping with opposition, the state both enlarged its competence and arrogated to itself more responsibilities. These responsibilities, however, subsequently became resources with which the locality fought both incorporation and exploitation. In the 1970s, this expansion of state activity took the form of wel- farism, and again it could be used either to insist on the rights of the conurbation of Los Angeles or to assert the contrary claims of the people of Owens Valley, this time in the language of environmentalism and the protection of collective natural assets. The legitimacy of centralgovernment intervention is thus seen to rest on justice, but then justice must in some measure be seen to be impartial. As Walton notes, "the state in modern society is both a relation of domination and an invitation to protest" (1992:307). That invitation will be accepted, in part, according to the strengths of local traditions of resistance, traditions that historical work might uncover and nurture. It is an invitation that Worster's pessimism leaves untheorized and unrecognized.

Finally, there is something distinctly nostalgic about Worster's evocation of an earlier, kindlier, Arcadian view of nature. As Cronon (1992c) shows, it replaces the "progress" narratives with "tragic" ones (see Table 1). These tragic visions rest upon, as White (1995:178) argues, the "demonization of modern machines and the sentimentalization of archaic forms of labor allow [ing] a bifurcation of work into the relatively benign and even instructive, and the modern and destructive." As White also suggests, this attitude may be an adequate basis for gardening, but it can hardly serve to address the sort of work from which people can make a living. White is surely right to argue that this leaves the world of modern work to the propagandists of large corporations, who are thus able to gather about them the shabby ecological virtue of "wise use" in a stand off where too many environmentalists argue for leisure amenities over any sort of productive work. The rigid dualism of this environmentalist perspective, as Cronon (1995b:81) has pointed out, ultimately leaves us with no place to think about humans as part of nature: "We thereby leave ourselves with little hope of discovering what an ethical, sustainable, honorable human place in nature might actually look like." Paradoxically, this strand of environmentalism remains within the tragic vision of the frontier thesis: "The frontier narrative was about settling a new land; it offered little wisdom about how best to live once the settling was done and the new land had become old" (Cronon 1992d:79).

In these ways, we may see how evaluating Worster's historical writings may, in turn, inform a critique of his values; how the circle between facts and values may be made virtuous through a consideration of how values direct inquiry but 
also of how inquiries should revise values. Worster is quite clear about this aspect of the New Western History: "The history of this region, if it wants to be vital and listened to, cannot be kept isolated from public controversy, struggles over power, the search for moral standards, or the ongoing human debate over fundamental principles and values" (1991:23). Worster's excavation and explication of those principles have been largely shaped by the Arcadian view of nature that he set out in his earliest work, but it would be unfair to give the impression that he only pays attention to social justice insofar as it is implicated in imperial attitudes towards nature. In a recent essay, Worster has contrasted Native American and European settlers' views of property rights. He argues that the American government violated the agreements they made with the Lakotas when they took their land. There are thus legitimate grounds for the Lakotas' claim on the use of the Black Hills. This claim need not rely upon religious attitudes to nature or upon historical precedence in occupying land. More simply, "[a] deeply felt wound that has festered for a hundred years might be healed and we could get on with the task of living with one another in mutual respect" (1992d:153). It is to such normative issues of fairness, redress, and social justice that I now turn.

\section{Justice and the Middle Ground}

Richard White has been concerned mainly with the history of Native American peoples and with the transformation of their ecologies under the impress of the frontier process. Like Worster, White echoes Horkheimer and Adorno (1979) in noting how the control of nature by some people may be the vehicle for the social control of other people. The monopolization of environmental resources by the new European settlers prevented the reproduction of the Native American way of life, leaving the aboriginal people, in economic terms, a dependent people. But White speaks from a more nuanced ecological and political position than has characterized some of the criticisms of industrial society that have animated Worster's work. Commenting on a paper by Worster (1990a), White (1990a) drew attention to some of the problems with Worster's ecological critique of capitalism and, in particular, to the difficulty of treating ecological climax as a stable measure against which the destruction wrought by human action might be measured. White has noted that historians have shown how extensive human modifications of the natural world have been over a very long period of time and have made "questions of climax and succession seem abstractions with few equivalents in the actual landscape" (1992a:xvii). He has also argued that just as environmental "causality" is complicated, so must be the "moral emphasis" of the historian (1990a:1114). (Cronon has remarked that "White's favorite ... way of describing the past is to say that it is 'complex'" [1992a:xv]). The development of White's work shows an increasing unease with some forms of ecological foundationalism and a growing recognition that the "[i] ssues of language, of discourse, of texts, and of creation of the subject that so occupy postmodernist scholarship are quite serious ones" (1992a:xvii). White's work, however, also rests on a belief that "[t]here was, and remains, a tangible physical world that sometimes affirmed but often mocked the representations designed to constrain it. For all the power of the postmodernist critique, it neglects this physical, tangible world, a world of substantial bodies, and trivializes our experience in it" (1992b:874). As a result of both of these views, White urges historians to explore the "interplay of ideational and material elements" (1990a:1116) in the replication and change of regional assemblages of people, animals, and plants. This interaction between culture and environment is a central theme of his work:

\begin{abstract}
Nature is at once a physical setting where living beings exist in complex relationships with each other, and a human invention. Humans create a shifting set of cultural concepts about the physical world and identify these concepts as nature. When they act, humans do so on the basis of these cultural formulations, but their actions rebound on an actual physical world. Recreating these cultural formulations for any given period is the problem (1985:306).
\end{abstract}

It might seem that this leaves little room in historical writing for explicitly normative concerns, and in rejecting reductionist accounts of the role of culture in environmental change, White underlines the problems this poses for the moral stance of writers such as Worster: "Historians would still lack the overarching standards by which we should judge change, but it is a pipe dream that we shall find such standards in either nature or history" (1990a:1116). Nevertheless, value judgments remain intrinsic to the histories White writes, and their negotiation is of special interest given his recognition of the force of both 
the antifoundational critique of ecology and the postmodernist critique of meaning.

White accepts the moral intentions of the environmentalist critique of modern American society, although he is unwilling to cast the attack in terms of a fall from pristine, natural grace. His argument appears to be that Euro-American attitudes to nature are so reckless of the demands of variety, sustainability, and security that acting upon them surely courts danger. More important, the Euro-American transformation of North American land has had tragic consequences for Native Americans that, alongside questions relating to nature, are pressing issues of social justice. Justice is the key term in understanding White's work. ${ }^{9}$ Operationalized in various ways, it connects both a moral critique of the consequences of the transformation of nature and modern political imperatives of redress owing to Native Americans to an empirical account of the cultural context of environmental change. Justice is to be found neither in nature nor in history, rather, it is something that we bring to our evaluation of the actions of human beings both in the past and the present.

Much as Worster has done, White understands the hubris of Euro-American attitudes toward nature. These attitudes entail dividing nature into those species that are useful to EuroAmericans and those that are not. Species, then, are of no intrinsic value. In his study of Island County, Washington, White notes that: "Americans reduced the complex view of the Indians to a few simple categories. The new farmers saw most native plants as simply 'weeds' or 'brush.' Land that grew these plants was, in the words of the census, 'unimproved' " (1980:41). This treatment of nature as resources and, given the nature of the economy, as commodities, directed the American gaze over the land. It embodied clear political choices in favor of certain uses (and users) of the land over others. For example, when, in exploring the American West in the late nineteenth century, Clarence King "chose to use the United States Geological Survey primarily to survey mineral deposits (rather than dam sites and water sources for irrigation), he chose to emphasize resources whose ultimate development would benefit mining corporations and not western farmers" (1991b:135). Similarly, in viewing their domesticated animals as "sentient tools" (1994a:238), Euro-Americans defined by default those other animals not subject to their will as useless enemies, creating a "biological monarchy where humans reigned, where uselessness among lesser living things was a crime punishable by death, and where enterprise was the reigning virtue" (p.257). Being ruled by enterprise entailed the production of a narrow range of species and crops, the latter of which were selected based on market prices rather than on immediate subsistence needs (1980:61-62).

As Cronon has argued, property relations partly connote ecological relations (1983:72). The creation of Euro-American titles to land largely mirrors the more general story of capitalism's primitive accumulation. White concurs with this assessment, noting that: "Americans believed that how they distributed the public domain determined the kind of society they were creating" (1991b:140). Land allocation was a contested act of remaking society after an agrarian ideal. Yet that ideal took many forms, from large ranches to small farms and from petty commodity production to wage and slave labor. Without regard for aridity or for the competing demands of grazing, logging, and mining, northern Republicans tried to allocate land in the West to homesteads of the size that had proved acceptable in the humid East. The demand for these homestead plots was limited by the failure of many small farms in the West. Yet loggers, ranchers, and miners continued to move onto public lands. The forms of access this latter set of users were eventually recognized as having still left the federal government with large property holdings in the West, in stark contrast to its much smaller holdings in the East. The survival of this public domain in the West owed much to the conflict between different varieties of the agrarian ideal, and to ecological realities such as the unsustainability of certain land uses given the physical conditions prevailing in parts of the West.

White traces the dominant role played by the federal government in directing economic development in the West to the retention of a large public-lands domain. This, in turn, was partly sustained by what many have seen as a fundamentally new attitude toward nature among early twentieth-century Americans: conservation. But here, White sees less discontinuity, linking conservation to an embedded instrumentalism characterizing American attitudes toward nature more generally. For him, conservation is simply a newly profitable use of nature as urban leisure ground:

The attempt to preserve these tokens of the natural world does not seem the outgrowth of any significant 
new attitude toward nature. The same basic standard, economic value, still governed the attempts at preservation. Remnants of the older natural systems have attained greater value as they grew more scarce and as urban dwellers gained the time and the means to enjoy them (1980:158).

White thus appears to endorse John Muir's criticisms of the utilitarian notion of monumentalism that motivated the preservation of certain natural landscape features in the U.S. He remarks that Muir "wanted nature protected so that humans might momentarily escape their human condition by mystical communion with forces greater than themselves" (1991b:411). As part of the conservation ethic, women and children were encouraged to appreciate nature as a repository in which "cute animals" were saved. Yellowstone Park, "[a]lthough presented as a salvaged remnant of aboriginal America, . . . by the late twentieth century came more to resemble a petting zoo with a highway running through it" (1994a:272). For men, on the other hand:

Sportsmen, as distinct from hunters, began to argue that a particular kind of virtue-hardiness, bravery, self-reliance-impossible to cultivate in an urban, industrial environment, was the true product of the hunt ... By the early twentieth century, they had clearly won their battle to protect game populations. By dying so that American males could maintain their virility and virtue, game animals achieved a symbolic utility and protected status (p.270).

The reference to Muir suggests some grounds for the implicit critique, but let us consider another line of criticism developed in these studies. In particular, White wants to draw attention to the survival of plant and animal species attendant with the Euro-American attitude to nature. Some consequences are unintended, many are indirect, and all are complicated. He believes that American society has not developed or empowered institutions that could monitor and control them: "Historically, the farmer, the lumberman, and the fisherman have proved more adept at refining technologies and increasing the scope and rate of environmental change than the larger society has been in gauging the consequences of the technologies and in creating institutional means to control them" (1980:159). In the absence of institutional checks, ecological crisis has proven a stern teacher. Euro-Americans have had to "put their ideological formulations of nature at risk in the physical world" (1992b:889).
In this view, Americans have paradoxically learned about nature from their failure to dominate it, whereas it is out of their subjugation of the Native Americans that their historical unlearning has sprung. At first, Native Americans and Euro-Americans "regarded each other as alien, as other, as virtually nonhuman" (White 1991a:ix). Although this view of the native peoples remained current back in Europe, immigrants and aboriginal peoples soon met on more equal terms in North America and forged a "common, mutually comprehensible world" (White 1991a:ix). Later, after breaking the autonomy of Native American peoples, Euro-Americans no longer feared nor felt any need to reach accommodation with them, and could then recreate "the Indians as alien, as exotic, as other" (p. x). At this stage:

The fact that Indians actually starved because colonizers had come, that they died in such prodigious numbers from disease in part because colonizers had wrecked their subsistence systems, and that these subsistence systems themselves were inextricably intertwined with the political, social, and cultural relations colonizers set out to undermine subverted the more beneficent rationale that colonialism brought a better life to all. Colonialists, therefore, tended to prefer imaginary pasts and more benign presents (White 1983:315).

In this imaginary past, Native Americans had not substantially changed the natural world: "[s]ince humans had not shaped the West into a landscape familiar to expectations conditioned by western Europe and eastern North America, they concluded that humans had not shaped the land at all" (White 1991b:57). The view that Native Americans merely passed over the land without leaving any trace has a number of consequences, one of which White mentions in his conversation with Cronon:

Actually this idea demeans Indians. It makes them seem simply like an animal species, and thus deprives them of culture. It also demeans the environment by so simplifying it that all changes come to seem negative-as if somehow the ideal is never to have been here at all. It's a crude view of the environment, and it's a crude view of Indians (Cronon and White 1986:20).

Faced with such unjust characterizations of Indians, the first task of the historian is to restore the dignity of historicity and culture to the Native Americans. E. P. Thompson made this point most eloquently when he spoke of "seeking to rescue" 
the artisans whose trades had been abolished during the industrial revolution, from "the enormous condescension of posterity" (1968:13). The hopes and aspirations of these people were meaningful in terms of their own experience and it is an abuse of hindsight to represent them as little more than doomed bystanders at the history of their own period. The right to a just hearing in historical writing is even more important in the case of Native Americans because, of course, they still live in America. Their survival and even, over the last century, their renewed increase in numbers, present a particular challenge to histories premised upon assumptions of white racial superiority or the inevitable disappearance of native peoples. As Berkhofer has written, this recognition changes the agenda of Native American history from a study solely of the relations between aboriginal peoples and European arrivals to one that explores cultural resilience on its own terms (1971). White's own approach is underpinned by just such an appreciation of Native American culture: "[t]he Bridges, Franks, and other families of the fishing rights struggles on the Nisqually and Puyallup rivers of western Washington first allowed me to realize the quite different ways Indian peoples can have of perceiving and organizing the world, and how tenacious and creative seemingly powerless people can be in fighting to maintain a way of life" (1983:xii). So, beyond the condescension that posterity brings, there is also a need to consider issues of justice in the present.

\section{Redress and Fairness}

I suggest that empirical questions are involved in these questions of justice, and that empirical research provides guidance in resolving matters of justice. To begin this task, I introduce two principles from the work of John Rawls: those of redress and fairness. First, redress:

This is the principle that undeserved inequalities call for redress; and since inequalities of birth and natural endowment are undeserved, these inequalities are to be somehow compensated for. Thus the principle holds that in order to treat all persons equally, to provide genuine equality of opportunity, society must give more attention to those with fewer native assets and to those born into less favorable social positions (Rawls 1972:100).

\section{Second, fairness:}

This principle holds that a person is required to do [their] part as defined by the rules of an institution when two conditions are met: first, the institution is just (or fair), ... and second, one has voluntarily accepted the benefits of the arrangement or taken advantage of the opportunities it offers to further one's interests (Rawls 1972:111-12).

White's work shows, first, that the unfavorable social positions occupied by Native Americans are undeserved, intentional consequences of Euro-American aggression and, second, that in no sense can Native Americans be said to have voluntarily accepted the arrangements under which they find themselves placed. The history of native peoples since the arrival of Europeans sustains claims on their behalf to a more generous settlement from Euro-Americans on the grounds both of fairness and redress. That realization, rather than being a concession to a more nuanced historical understanding, has actually come from the continued vitality and demands of the First Nations themselves. Just as the agenda of social history more generally has been shaped by the demands of the new social movements, so writing about Native Americans has been shaped by their demands. A book such as David Wishart's An Unspeakable Sadness is decisively framed by the cases put by native peoples to the Indian Claims Commission after 1946. The claims process, which invited final settlement of outstanding grievances through providing compensation for earlier forced, illegal, or unfair land sales, assisted in the reassertion of native rights and identities that has forced itself upon the attention of historians and historical geographers. Instead of the final settlement resulting in the complete $a b$ sorption of native peoples into the federal polity, it has in fact produced a deeper pluralism and separatism.

Writing of the Indians of Island County, Washington, White notes that: "[t] hrough observation and tradition, Indians altered natural communities to fit their needs without, in the process, destroying the ability of those communities to sustain the cultures that had created them" (1980:25). At several points, he comments on the way some groups of native peoples used different resources, often in different places and at different seasons, to secure a living from the land. In some cases, they farmed part of the year and 
hunted the rest. In many cases, they had both a primary and a secondary food cycle so that if one set of food sources failed them, they could get by with others. Seeking food security rather than maximizing production, Native Americans had a number of ways of ensuring sustainability. They regulated the exhaustion of the land by moving their fields after a period. They controlled fertility through hunger and, in some cases, infanticide. The game they hunted thrived in the contested borderlands between Indian tribal groups or villages. In killing game, they took what they needed for survival. This was all very different from the attitudes of Euro-Americans. For example, in contrast to the Euro-Americans' instrumental view of animals:

Indian religions made hunting holy and gave human-animal relations a depth and complexity largely lacking among Europeans. In hunting, some persons died so that others might live. Ceremonies preceded the kill. Animals consented to die; they, or more powerful beings-holy people, keepers of the game, or other supernaturals — pitied the hunter and instructed him in the rules and rituals necessary to kill them. Indians killed game as much by prayer, pleading, and reverence as by the arrow or spear. They recognized the obvious wariness of game and the reluctance of animals to die, but they explained it in terms of previous ritual abuse by humans or even supernaturals. The difficulty of obtaining the consent of animals only made strict observance of hunting rituals all the more necessary (White 1994a:237-38).

European colonization made it impossible for Native Americans to continue with this way of life. Euro-Americans granted themselves exclusive title to parts of the natural world that were crucial to the spatially dispersed, complementary food cycles of the Indians: "[i]n a society in which law, rather than tradition or religion, increasingly defined man's relationship with the land and sea, the Salish became a people literally without rights. They were cut off by law from centuriesold fishing grounds, and the state allocated their catch to white commercial fishermen" (White 1980:72). Settlers' farms hemmed in Native American periodic and dispersed land clearances, leaving them nowhere to move when the soil neared exhaustion. Ultimately, attacks on the religions of native peoples made their regulation of population numbers impossible. A conscious policy of creating dependence among the Native Americans through debt and alcohol allowed Euro-Americans to secure ever more furs from some groups of native peoples, enhancing the importance of warriors over peacekeepers and further compromising subsistence activities. This deepening involvement with the fur trade in the Great Lakes region "gradually created new meanings and altered the meanings of old objects" so that, for example, while anyone could move into tribal territories and kill game if they were hungry, only people with local rights were permitted to take away the furs, which could then be exchanged for European goods (White 1991a:103-04). The stabilizing institutions of Indian society that ensured ecological sustainability were undermined, and "[a]lthough they had once been able to feed, clothe, and house themselves with security and comfort, Indians gradually resorted to whites for clothing and food," until "[i]n the end, whites specified what was to be exchanged, how it was to be exchanged, what the Indians were to receive, and how they were to use it" (White 1983:xix). To reach this point, the settlers had waged explicit war upon Native American subsistence systems. Preventing $\mathrm{Na}$ tive Americans from gathering food, for example, was often a bitterly effective tactic against such militarily powerful, recalcitrant tribes as the Lakota (White 1991b:104). Peoples such as the Salish were gradually forced out of the wider American society and consigned to the refuge of small, dedicated reservations (White 1980:73).

Before this point was reached, native peoples had made many creative attempts to adjust to Euro-American demands for resources and to military and biological threats. Their sustainable agricultural systems did not collapse from within in some Malthusian fashion (White 1983:316). Rather than passive impediments to European expansion, Native Americans sought many and varied forms of accommodation with the imperialists. Historians do them an injustice when they fail to recognize this, treating Native Americans as an ahistorical entity mired in traditional, internecine strife (White 1978:343). Political forms such as villages, tribes, nations, republics, and ultimately ethnicities were institutions shaped and reshaped out of this creative adaptation. To restore this complexity to the historical picture is not only to do the Indians descriptive justice, it is also to document the explicit aggression by which Native Americans were forced off the middle ground of compromise and coexistence and marginalized as part of a social contract they can hardly be said to have chosen. The story of how Native American society was underdeveloped, 
then, serves as an explicit rebuke to the supposed equality of all before the law. Nevertheless, White's studies also provide empirical grounds for maintaining that alternative arrangements are imaginable in the present. This is true both of the importance of Native American theories of nature and of the tenuous achievements of the middle ground. I now turn to these two lessons of history.

\section{Two History Lessons}

For White, the contrast between Native and Euro-American ways of relating to natural resources is an instructive one: "[w]e can't copy Indian ways of understanding nature, we're too different. But studying them throws our own assumptions into starker relief and suggests shortcomings in our relationships with nature that could cost us dearly in the long run" (Cronon and White 1986:25). Clearly, these lessons include the importance of sustainability, but White is also anxious to contrast the views of native peoples with those of romantic conservationists: "One thing that has impressed me about Indians I've known is their realization that this is a harsh planet, that they survive by the deaths of other creatures. There's no attempt to gloss over that or romanticize it" (p. 20). The second historical lesson drawn by White concerns what he terms the middle ground. On this middle ground, until the autonomy of Indians had been broken, whites and Indians found ways to share notions of justice, price and fair play despite the very different repertoire of cultural resources they brought to the exchange, a tribute to the ability of people to empathize with each other's frames of reference sufficiently to make themselves comprehensible in terms of each other's presuppositions. This rapprochement undermines the pessimism implicit in radical cultural relativism. It provides grounds for both a recognition and a suspension of difference that allows us to respect and grant rights to the "other." Culture shapes our treatment of other people, as well as our treatment of the environment, but this is not a view of culture as incommensurability: we can find ways to accept alterity and still reach a mutually comprehensible and acceptable accommodation with the "other." In a recent paper, White has documented how General Custer and Sitting Bull became central elements in the respective mythologies of Euro- and Native Americans, while also showing how the mythologized Custer and Sitting Bull migrated across this divide and became reworked elements in the stories of both cultures. Invoking a sense of history as storytelling, White suggests that "[t] hese stories we tell about the West matter. They not only reveal how we think about ourselves, they help determine how we choose to act towards each other" (1994b:55). The meandering of stories between cultures suggests that while myths and legends "told about the frontier and the West have certainly not always been told with democratic intent ... they have had democratic consequences. Attempts to close them off, to confine their possession to certain groups, have failed. They have become democratic stories inhabited by diverse Americans and open to multiple retellings ...." (p. 55). This "imaginative coherence" speaks to the possibility of a tolerant pluralism. In this sense, by telling the story of Native American peoples in terms of their own understanding of social and environmental change, White is providing the empirical basis for justice claims of fairness and redress. He is providing a just description, restoring agency and dignity to the native peoples about whom he writes. He is providing the prescriptive basis for justice claims of redress. Native Americans continue to be without full equality of opportunity in the U.S. due to the imposition by force of a social contract to which they did not assent. White is, finally, helping establish the bonds of common humanity (empathy) and plurality (solidarity) which enable those justice claims to be heard. This is a subtle interweaving of empirical and normative concerns, but I believe it offers more than a naive ecological foundationalism or a postmodern cultural relativism.

\section{Citizenship and Regionalism}

Patricia Limerick has been a staunch critic of the legacy of Turner for its ethnocentrism, its narrow view of the economy, its omission of women, its cavalier disregard of environmental degradation, its severance of nineteenth-century history from twentieth-century politics, and, finally, because it "blurs the fact of conquest and throws a veil over the similarities between the story of American westward expansion and the planetary story of the expansion of American empires" (1994a:75). She has contended that all attempts to rescue the Turnerian emphasis on the American West as a process, such as those of 
Aron (1994) and Cronon et al. (1992), inevitably privilege the Anglo-American movement from East to West over all other population movements and ethnic identities, including not simply Native Americans, but also Latinos, Asian-Americans, and African-Americans. Yet, in a recent paper, she offers a definitional truce on the grounds that a survey of the uses made of the term "frontier" in some four thousand newspaper headlines has convinced her that the American public cares little for these academic squabbles and continues to use the term "frontier" in an overwhelmingly positive manner. The "frontier" has become "a kind of multicultural common property" that "works as a cultural glue-a mental and emotional fastener that, in some very curious and unexpected ways, works to hold us together" (Limerick 1994a:94). This is somewhat similar to White's emphasis on the imaginative coherence offered by common stories, but Limerick is more explicitly concerned than White with the links between this public consumption of history and the public role of the historian. I argue that the central normative concern of Limerick's work is with citizenship, and that she seeks to ground the claims of citizenship in an avowedly regional political community.

\section{The Public Intellectual}

Limerick is anxious to engage in a debate on the nature of western history beyond the academy, and is delighted to find that increasingly possible: "[a]ll around the West, the public is eager to join in this discussion, giving western historians in the late twentieth century the finest opportunity imaginable to revive the role of the western public intellectual" (1991a:77). This will only occur, however, if historians face some painful realities and become more self-consciously engaged, and this will involve a transformation of history itself: "The transition from a historical profession intoxicated with the dream of objective, neutral, value-free inquiry to a historical profession aware of, and honest about, the unavoidable reality of subjectivity, is, understandably, an awkward and uncomfortable one" (1992a:135). Indeed, Limerick notes that those who have wished to restore the Old Western History have done so largely in the name of historical objectivity, yet: "[a]lthough they thought of themselves as rigorously neutral, without ideology or bias, they had in fact placed their sympathies with English-speaking male pioneers and then called that point of view objectivity" (1991a:67). For example, in a paper on the work of Ray Allen Billington, Limerick documented the way his historical studies treated all ethnicities other than Anglo-American as barriers to American progress, giving minorities little attention in their own right. She recognizes Billington's personal "rejection of bigotry," but she notes that this led him to avoid recognizing adequately the importance of racial difference in historical interpretation: "[e]ven if we should prove able to write of our future without reference to racial differences, we will never gain that license in the writing of the actual, not the imagined, past" (1991b:306). On the other hand, she has nothing but praise for Wallace Stegner, whose wartime propaganda book, One Nation (1945), looked without blinking at the racism of contemporary society and warned Americans of its insidious effects: "we are much in his debt because he said these things so clearly and so forcefully, before many others were saying them, or even thinking them" (1993b:65). Public intellectuals, then, must recognize and articulate their personal subjectivity in the context of a wider field of subjectivities and experiences.

In Limerick's case, an individual voice is grounded in her upbringing in Banning, California. At several points, she insists that the romantic myths of the Turnerian frontier find no purchase in Banning: "[t]ailored to fit Portage, Wisconsin, Turner's frontier theory simply won't fit Banning, regardless of how you trim and stitch, tighten and loosen" (1991c:82). Her childhood bore testimony to a different story:

I grew up in Banning, California, where one town patriarch made much of his money providing the prostitutes for the workers building the aqueduct taking Colorado River water to Los Angeles. Outside Banning was the Morongo Indian Reservation, and kids from the reservation were with us in school until about the eighth grade, and then, when we graduated from high school, most of the Indian kids had dropped out. How, in other words, could I have acquired illusions about western history? Illusions? In Banning? (Worster et al. 1989:321-22).

It is clear, however, that this is the product of retrospective reflection, for elsewhere she says of her childhood that: "I took the landscape for granted, and I had no uncertainties about water, even if I also had no idea where it came from" (Limerick 1985:13). This retrospective reflection is through the lens of her subsequent political 
education. To a large extent, the values that inform Limerick's history come from an acceptance of the liberal agenda of the 1960s. She refers to herself as a "palaeo-liberal" (Worster et al. 1989:321), remarking of the New Western History: "The influence of perspectives originating in the 1960s is unmistakable" (Limerick et al. 1991:x). The New Western History registers the effect of the new social movements on the agenda of social history: "In the broadest sense, the 'New Western History,' is simply the aggregation of studies of race, gender, class, community, economic dependency, and the environment in the West conducted over the last twenty-five years" (White 1992c:10).

Yet feminism, multiculturalism, and environmentalism make legitimate claims upon the historian's attention, claims that go beyond both the band-aid of a parenthetical "political correctness" and the "conjunction school of historical revision" (Limerick 1991a:64), which simply adds new sections to old textbooks. 10 The exclusions and elisions in the Old Western History result in explanations of the past that are inadequate even on their own terms, and which fail to confront the historical construction of political identities in the present. What I have described as the virtuous circularity of facts and values, Limerick refers to as a spiral. Writing of the work of the landscape photographer, Mark Klett, she remarks that " $[\mathrm{t}]$ hrough his experience in the Rephotographic Survey Project, Klett came to know, first-hand, that we live in a relativistic universe, where an individual photographer can, by the choice of his vantage point, change what we think of as reality"; but by looking again, longer and harder: "[t]he path of perception of the American West thus traces a spiral, as Euro-Americans have, over time, gotten 'warmer,' closer to the center, but by no means all the way there" (1992b:108-09). Elsewhere, and more ingeniously, Limerick uses the metaphor of conversation for this relationship between perspective and scholarship.

\section{Conversations on the "New"}

Despite her despair about the influence that academic debates over the meaning of the "frontier" are having on the uses of the term in public discourse, Limerick is anything but pessimistic about the potential importance of clear historical writing for the contemporary construction of political identities. Limerick coined the phrase
"New Western History" for a symposium held to launch a touring exhibition about the history of the West. The phrase, and the brief explanation she offered about the movement, were taken up in a variety of news media including the Washington Post, the New York Times, and National Public Radio (Limerick 1991a:61).

Even more dramatically, the revisionism of the New Western History was on display at the Smithsonian Institution National Museum of American Art in Washington, in an exhibit entitled "The West as America: Reinterpreting Images of the Frontier, 1820-1920," where it offended the patriotism of some Americans still basking in the aftermath of the Gulf War. The labels in the exhibit "redefined many western artists as apologists for Manifest Destiny who ignored or were culturally blind to the displacement of indigenous people and to the environmental degradation that accompanied the settling of the West" (Gulliford 1992:200). The media uproar was extensive. More than seven hundred people entered their reactions in the comment books, the majority being positive (Truettner and Nemerov 1992:70). Yet critics were bothered by the suggestion that great art was anything but objective reporting and America's frontier not the leading edge of world civilization. Daniel Boorstin characterized the exhibition as "perverse, historically inaccurate, destructive" (Gulliford 1992:201). On the five-hundredth anniversary of Columbus, the American public objected so strongly to a section on "Inventing the Indian" that the text on the labels was toned down. This public interest suggests at least the possibility of a conversation.

Conversation is important to Limerick. She celebrates dialogue: "Each incident . . . in which Westerners of these various backgrounds and convictions defy the odds and choose not to attack each other, nor to evade each other, but to converse-each of these incidents seems to me powerfully freighted with hope" (Limerick 1991d:45). The development of a responsible and democratic politics in the West depends upon such a dialogue: "The human diversity of the West remains ... a conversation waiting to happen" (Holthaus et al. 1991:9). This is where she places her hope: "Although there is no reason to argue that residents of the West now live with an enlightened regional self-consciousness based on ... elements of commonality, there is also no reason to argue that they could not or should not" (Limerick 1991a:71). A more adequate understanding will require a true appreciation of the dis- 
tinctiveness of the West as well as an appreciation of the experiences and expectations of the diverse human groups sharing the land. In a sense, Limerick wants regional identity to suspend ethnic difference. The West should thereby define an imagined community to which all could belong. In this view, Stegner is a sympathetic figure not only because he urged the cause of antiracism against the danger of the U.S. "balkanizing," but also because he longed, in his own words, for "a past to which [he] could be tribally and emotionally committed" (quoted in Limerick 1993b:66).

Here, the legacy of Turner seems particularly pernicious. In treating the West as a process of frontiering ending in 1890, Turner not only cut the modern West off from its past but also made it the temporary adjunct of a story of national history which returned to the East and, especially, to the Midwest. Limerick complains that too many modern history textbooks do much the same as Turner in this regard: "[r] egardless of the politics, the methods, or the ages of the textbook's authors, the West registers as a transitory phase of national history and not as a permanent place" (1992c:1383). The marginal place given to the West in national history offends her regional pride. Limerick believes, further, that it is only upon a version of regional pride that an enlightened tribalism might be founded. She finds this resurgent self-confidence in environmental science, literature, painting, and photography; hence her enthusiasm for the work of Mark Klett: "[i]ntentionally or not, the Rephotographic Survey Project rejected the abstract, shifty definition of the West as a frontier, and saw the West as a set of solid and continuous places. The project by its very nature assumed a connection between the western present and the western past" (1992b:13). For Limerick, this is the cultivation of "hindsight without smugness" and is "the use of the mind that western historians, as well as westerners in general, most need to develop" ( $p$. 13). The West was and continues to be important, at least in part, because its past and present teach the fundamentally multicultural and environmentally grounded character of American society: "With our variety of ethnic backgrounds, occupations, lengths of residence, passions, convictions, ambitions, expectations, and regrets, we are in this land, and in it together" (1992b:110). For Limerick, the task of the historian is to promote that sharing of experience. Referring to the West as a Babel of different languages, she writes of the "spirited intellectual effort of communication" (1992d:176).

Yet dialogue has all too often been wrecked upon the shoals of Western experience: "First, Americans came West with high hopes for improved personal fortune, hopes that carried both the seeds of disappointment and frustration and, not far beyond, the need for someone to blame. Second, scapegoats were everywhere at this crossroads of the planet, the meeting ground of Europe, Asia and Latin America" (Limerick 1987:269). The historian can at least restore to all groups an acknowledgment of their joint work in shaping the region. By emphasizing the idea of the West as a meeting ground, she suggests, "we would have an equitable and accurate way of giving all the participants their due" (Worster et al. 1989:317). Turner's story left one group in the field as conscious actors and the rest as mere friction to the progress of civilization. On the other hand, "The complete story of the investment of human consciousness in the American landscape requires attention to the whole set of participants - indigenous people as well as invaders, eastward-moving Asian-American people as well as westward-moving Euro-American people. With anything less, the meaning of the landscape is fragmented and truncated" (Limerick 1992e:1026).

\section{Using the Western Landscape}

Worster raises an important question when he asks whether Limerick's Legacy of Conquest presents the West as primarily a failure of democracy or of ecological sustainability (Worster et al. 1989:306). The environment is certainly a central concern of Limerick's work, but the tragedy of environmental destruction is not the leitmotif of her work as it is of Worster's. In Desert Passages (1985), Limerick looks at writings about the deserts of the Southwest U.S. and documents the various ways the desert has been presented as obdurate and initially uncooperative nature. In thinking about the effect of aridity on attitudes to nature, for example, Limerick offers the desert as an occasion to think about limits. It is not aridity, as such, but reflections upon natural limits to which it has given rise that interest her, and which give her hope that people in the region might learn and impart lessons about the dangers of imperial attitudes toward nature. This recognition of limits is now available to the nascent 
regional self-consciousness to which she wants to contribute. Thus, while recognizing that it does not cover all of the region, she insists on aridity as a defining characteristic of the West (1987:135). Aridity has been important at various points in defining the historical trajectory of large parts of the West; it has been one of an important set of contingent differences marking the West from the rest of the country (see also White 1991c:38-39). There is something to be learned from the legacy of aridity, just as there is something to be learned from the legacy of ethnic diversity, and Limerick's western selfconsciousness needs to be fueled by both.

Her concern to use the landscapes of the West as a corrective to smug histories of Anglo-American success informs another collaboration with Mark Klett on the mining "ghost town" of Rhyolite. Noting that C. Vann Woodward had declared that, in its confrontation with failure, the history of the South taught distinctive and serious lessons to all Americans, she offers the West as a landscape teaching related lessons in failure:

\begin{abstract}
Although the two kinds of regional failure are very different, ghost towns give the West its most visible credentials in failure. The impermanence of many western enterprises confronted many people with the frustration of failed expectations and ambitions. Add the fact that the gain of any individual or group in the West often rested on a corresponding loss for another individual or group, and the West, as well as the South, can act as a corrective to the idea that U.S. history is a "very monotonous repetition of successes." The West becomes, thereby, what the South has long been-a region to take seriously (Limerick 1994b:43).
\end{abstract}

The town of Rhyolite, then, rested upon "the narrow and precarious foundation of extractive industry and unrestrained economic ambition" and its failure stands as testimony against both in this manner: "Haunted by this hard-edged, uncompromising ghost town, one is encouraged to consider other, firmer foundations for society" (Limerick 1994b:46). There is, then, in Limerick's work, an urgent wish to teach the lessons of the contradiction between unrestrained economic expansion and the limits set by aridity and finite resources.

These aspects of environmentalism, though important, are not the dominant themes in her reflections upon the history of the landscapes of the Southwest. For that, Limerick turns to landscapes as the common ground of ethnic diversity. She claims that: "[t]he strategy of keeping a focus on the place and its physical conditions allows an author to include Indians and Euro-Americans as people of equal significance and dignity" (Worster et al. 1989:319). Such common ground becomes sacred ground: "Where people have labored, suffered, struggled, or even just survived, they have planted seeds of memory as directly as farmers sow crops, and memory has its roots in the soul" (Limerick 1992e:1026). The historian needs to engage with the contestable tangle of memories - the ghosts of our landscapes - and through taking up the landscape perspectives of the many different groups involved in the making of those landscapes, the historian can advance a conversation about democratic politics. This is a particular obligation on Euro-American historians, since they have benefitted from a truncated conversation that legitimizes their privileges. Indeed, the Anglo-American obsession with constructing community out of written law may now provide resources with which Indian legal activists can reanimate treaties formerly honored most frequently in the breach, using them to press new claims (Limerick 1987:331). Landscapes provide both the common ground of a shared history and the object of much conflict, plunder, and litigation. Language, community, and contract; these define citizenship in the Western Babel. Historians can join activists in breathing life into sclerotic contracts, in translating diverse experiences into claims on common decency, in lending an ear and a voice to the subaltern. In this spirit, Limerick moves between modern politics and New Western History, directing both to the dilemmas of the structured inequality of Western multiculturalism.

In summary, Limerick wants to use something akin to citizenship as a yardstick against which the multiculturalism of the modern West is measured and found wanting, and she wants to use the idea of a common regional history to build bridges across the ethnic divides. Given her emphasis on conversation and on landscapes in common, the major difficulties with her approach to the virtuous circle between facts and values lie in the extent to which a genuine regional self-consciousness can become politically effective and the extent to which landscape can do service as a metaphor for actions with commonly shared ends without becoming too vague. ${ }^{11}$ The first stage in her model of paradigm change in history, which involves demonstrating that history's claims to objectivity are spurious, has largely been achieved. The second stage involves changing the public's view of 
history. Here she can point to the publicity around the New Western History as evidence that the argument has leaked out of the ivory tower and is now being engaged with by a broader public. She might even claim that the book commissioned by the Western Governors Association, Beyond the Mythic West (1990), suggests that politics with a capital "P" has been influenced by these academic debates.

\section{The Virtuous Circle of Facts and Values}

I have argued that Cronon's work is informed by the priority that an ethics based on sustainable development might give to environment in the description of social and economic development. I have proposed that Worster's account of nature's fall from grace under Euro-American imperialism rests upon a demonization of technology. I have suggested that White's concern with justice for Native Americans directs his attention towards the common ground on which such claims might be heard. I have described the way citizenship serves in Limerick's work as a yardstick, calling the sins of the past to account in the claims of the present. I have shown that these normative frameworks produce narratives that pose both empirical and ethical challenges. When Cronon adopts a neoclassical account of the way nature is embedded in economy, I find the explanation less satisfying than the attention given elsewhere in his work to the social context of resource use. When Worster demonizes technology, he leaves little scope for recognizing the forces of resistance on which our hopes for the future might be based. White's reticence about the moral conclusions he draws from his work can give the impression that empirical complexity is the inevitable nemesis of social justice. Limerick's focus on conversation prioritizes the development of consciousness over an account of the material changes that the consciousness is attempting to articulate.

In conclusion, I suggest that in the scholarship of the New Western Historians, we can discern two moments in the virtuous move from facts to values. To do so, I draw on Seyia Benhabib's terms of norm and utopia (1986; see Table 2). Social critique based on norms holds society up to its self-professed principles and measures how far it falls short, rather like Limerick's evaluation of how ethnic diversity is treated today. Beyond that, we might look to the new values that are not yet the consensus but that form the basis for new agendas that go beyond what is already implicitly conceded in principle even if not in practice. This norm-based form of critique Benhabib terms immanent, for it anticipates little more than the fulfillment of the currently declared social project. In contrast, utopian critique is anticipatory. It projects a future based on the transfiguration of the current agenda. Benhabib describes the nature of immanent critique in Hegel and Marx where the human subject, which was to be the bearer of historical change, was an individual who either thought (Hegel) or worked (Marx). Benhabib argues that, in the case of Marx, this work model of human action privileged humanity as individual tool user over all other conceptions of humanity. In particular, she argues that Marx left undeveloped those parts of his work that dealt with language as the model of the individualin-social relations. Language presupposes a community of language users. Communication is inherently participatory and collective. These areas based on intersubjective interaction suggest an alternative set of relations beyond the essentially juridical concerns of holding society to its declared principles. Beyond the world of rights and entitlements, there is one based on needs and solidarities that anticipates a future world where

Table 2. Critique, Norm, and Utopia According to Benhabib

\begin{tabular}{lll}
\hline \multicolumn{1}{c}{ Basis of Critique } & \multicolumn{1}{c}{ Norm } & \multicolumn{1}{c}{ Utopia } \\
\hline Form of critique & Immanent & Anticipatory \\
Orientation to current social project & Fulfillment & Transfiguration \\
Human activity & Work & Participation \\
World of values & Rights and entitlements & Needs and solidarity \\
Human subject & Collective singularity & Participatory pluralism \\
Conception of the "Other" & Generalized & Concrete \\
\hline
\end{tabular}


plurality is recognized and a communicative ethics has a fuller chance to develop.

This division has obvious implications for the earlier discussion about the shortcomings of the emancipatory project implicit in the marxist labor theory of value, which, in Benhabib's terms, is a normative rather than utopian critique of capitalist society. Whereas the project of communicative ethics that she takes from the work of Jürgen Habermas promotes citizenship as participation in a social conversation, Marx's labor theory of value treats labor as a universal class that can act in the name of society as a whole to end exploitation by recovering alienated labor or capital for the proletariat. This view, according to Benhabib, is fundamentally dogmatic. It denies the plurality of identities in society, many of which serve as the basis for experiences of solidarity and respect which equally anticipate utopian needs going beyond what the currently recognized principles of rights and entitlements would allow. Instead of the collective singularity of the proletariat with all the authoritarianism and subjection of means to ends that this entails, Benhabib urges attention to the project of participatory pluralism.

This position finds echoes in the work of Cronon and Worster, and the emphasis on participatory pluralism and society as an ongoing moral conversation speaks to some of the central concerns of White and Limerick. Cronon is explicit about the way environmentalist history might "teach us the stories ... that will help us to live better, more responsible lives" (1995a:50) and "keep us morally engaged with the world by showing us how to care about it and its origins in ways we had not done before" (1992c:1375). I did not, however, introduce this brief account of the work of Benhabib simply to reinforce those normative orientations nor to reinforce my claims about the limitations of the Marxist normative project. Rather, the nature of the moral conversation, according to Benhabib, creates a special role for the sort of empirical contextualization that good historical and geographical explanation provides. Benhabib argues that we have reached the point in the development of the moral conversation where it is possible to recognize that it entails universal moral respect and egalitarian reciprocity (1992:30). The moral conversation will produce ethically correct conclusions if all are entitled to be heard and if all can raise topics for consideration. Participation in such a conversation will deepen people's sense of civic friendship and solidarity (p. 11). People will come to take account of what would be the point of view of the other participants in the conversation both because they feel this sense of solidarity and because they know they need to get the informed consent of the "other" to any proposals they raise.

Not everyone will be persuaded that a common moral conversation can indeed build consensus on substantive ethical and political issues. For example, Willems-Braun (1997) questions the likelihood of the suspension of political and economic inequalities or the supersession of biased "common sense" in fora such as environmental roundtables: "Although these arenas do often increase possibilities for participation, they do not by themselves mitigate the relations of power that are inscribed into public debate through the categories and identities by which conflicts are organized and understood" (1997:26-27). There is clearly a dangerous essentialism were one to see the ideal speech situation as uncovering rather than merely helping constitute an ethical common ground. Yet, the antiessentialist position comes quite close to that sketched out by Benhabib when Mouffe follows Rawls in speaking of overlapping consensus, of "creating a link between recognized principles and hitherto unformulated demands" (1993:54) — and even more strongly when she describes politics as a language game that is about finding "new usages of the key terms of a given tradition, and of their use in new language games that make new forms of life possible" (p. 17). The major difference comes when we turn to examine the proposed content of this overlapping consensus. For Mouffe, it is primarily procedural. People need to develop a commitment to the fact of political conversation in its democratic variant. As long as they share the conversation, they suspend the potential violence of the differences that brought them onto the conflictual terrain of politics. Yet, if democratic subject positions are to be rendered attractive by showing how they address the needs of the overlapping groups of subjugated persons, I see, with Limerick, no reason why that should not translate into the perception of overlapping material interests in fairness and in a more egalitarian economic order. To some extent, Mouffe acknowledges this in noting that democracy exists in a field of tension between equality and liberty. Yet she is very suspicious of any suggestion that rational debate might converge on a common conception of what might constitute the good life. Society is too pluralist for that. Yet, in Benhabib's defense, it 
might be suggested that the other-regarding dimension of civility need not entail loyalty to a single vision of the good life but might allow overlapping gestures of egalitarianism which acknowledge certain common claims of the humanity we accept as fellow citizens in our polity. Some of these claims may well be material (to shelter, to food, to education, to a tolerable standard of living) but, whatever form they might take, it seems obvious that they will only develop out of the common feeling that comes from interaction and mutual knowledge of the conditions of life across different sets of identities.

This is very much like White's discussion of the middle ground. But the importance of empirical work takes us further than this. An understanding of the "other's" point of view entails recognizing both the specific differences that frame worldviews and the particular context in which those framings take place. Beyond the broad respect and particular rights due to the generalized other, there must be, asserts Benhabib, a recognition of those entailments due to the concrete or specific "other." That recognition, in turn, requires the skills of contextual judgment (p. 53), skills that rest upon a sensitivity to the particular-a sensitivity that good historical and geographical explanation can advance. Empathy can allow us to imagine when we need to extend the rights of the generalized "other" in any particular context, but empathy too readily erases differences. Only the voice of the other can adequately alert us to plurality and difference. Historians of subjugated ethnic groups and of women have persistently made this point and, as Limerick explicitly concedes, have made possible the new syntheses through which the New Western Historians have confronted some of the central myths of Anglo-American identities. If historical and geographical writings can build on this work of the New Western Historians and continue to attend to the sets of agenda of those groups in subjugated positions, then the circle between facts and values will indeed have turned virtuous.

\section{Acknowledgments}

I would like to thank Stuart Corbridge, Bill Cronon, David Demeritt, Jim Duncan, Ken Hillis, Steve Hoelscher, Phil Howell, Hannah Moore, Pete Morris, Yi-Fu Tuan, and Jeff Zimmerman for their help. I would also like to thank Don Mitchell for the invitation to present this paper to the Association of American Geographers' Annual Meeting in San Francisco, in April, 1994.

\section{Notes}

1. In this paper, I shall take up the first set of criticisms in some detail but shall say less about the second. The very possibility of the virtuous circle of facts and values that I describe is denied by the more radical versions of postmodernism. The position implicit in my remarks here might perhaps be termed neopragmatic. In general terms, I am something of a falsificationist, although in practical terms, the verifactionist calls the glass half full, whereas the falsificationist says it is half empty. I believe that value positions rely upon making claims about the consequences of certain actions based upon conclusions drawn from observations of similar actions in other contexts. These observations are subject to empirical falsification, and the conclusions drawn from them are subject to objection on grounds of logic or plausibility. I develop this point a little more fully in the conclusion.

2. White (1994b) describes the Roosevelt position as Buffalo Bill Cody's, and sees a complementary tension between Turner and Buffalo Bill. Between them, the arguments of Cody (or Roosevelt) and Turner prefigure the whole discussion of the frontier in this century. Regardless of precedence, the central point still stands that the two positions construct different stories from different points of view.

3. Merchant (1989) is among the many historians who share this view of the development of the U.S. as essentially a frontier process. Indeed her two ecological revolutions, the colonial and the capitalist, succeed each other in each place as the frontier moves westwards. In her terms, Cronon's Changes in the Land is essentially about the colonial ecological revolution, whereas his Nature's Metropolis is essentially about the capitalist ecological revolution.

4. Marx would not have used the term "utopia" in the way I do here, for it was precisely the implausibility of the dreams of some socialists that led him to distinguish their "utopian" approach from one such as his own that was grounded in the material tendencies/possibilities of the contemporary age and thus perhaps deserved the term "scientific." In commenting on Bakunin's attack on his work, Marx noted that the phrase "scientific socialism" was "only used in opposition to utopian socialism, which wants to attach the people to new delusions, instead of limiting its science to the knowledge of the social movement made by the people itself' (1974b [1874-75]:337). Engels, from Socialism: Utopian and Scientific (1993 [1880]) onwards, made explicit use of this distinction. I want to retain the term utopian, however, to describe the imagined future world that helps us to think critically about our own times. I also 
use it to stress the degree of choice involved in normative issues so that we avoid the implication that a better future is somehow inevitable.

5. Even here, I am disturbed by the dogmatism and disciplinary chauvinism of some of Cronon's critics in geography. To suggest that if Cronon had written about a later period, he would not have been able to avoid issues raised by Chicago's transition to an industrial economy, seems to me to be beside the point (Pudup 1994). Page and Walker's attempt to correct Cronon's "unsustainable assumptions about the primacy of intraregional trade" by asserting that " $[\mathrm{t}]$ his point was made definitively by geographers decades ago" (1994:153; referring, I suppose, to the work of Allan Pred) ignores the work in economic history that has at least kept the question open (e.g., Lindstrom and Sharpless 1978).

6. In recognizing the links between questions of strategy and those of truth, I do not want to allow the one to be collapsed into the other. This is what Demeritt proposes in his "politics of truth," suggesting that we need "to evaluate competing accounts, not in terms of their truth or falsehood, but in terms of their likelihood to produce the kind of world we hope to live in and leave behind us" (Demeritt 1994a:31,34). Drawing on Wolff and Resnick's work, Graham makes much the same case for Marxist economic geography (Wolff and Resnick 1987; Graham 1990). Yet discourse, it seems to me, should only strive to produce a better world by persuading people of the truth claims it makes. As Cronon replies to Demeritt: "Without some faith that our descriptions of reality bear at least tangential relationship to that reality, it makes little sense to worry about reality at all" (1994b:42).

I am not willing to allow that the distinctiveness of Cronon's position is purely metaphorical. I find much of value in Demeritt's account (1994b) of the consequences of various metaphors of nature in the work of Cronon and, particularly, of Worster. Demeritt suggests that there are ontological and epistemological chasms between the environmental historians' metaphor of nature as an active agent and the new cultural geographers' metaphor of landscape as text. The two positions see different things and accept different procedures of exemplification and verification. This particular distance may well be reduced by searching for a common metaphorical ground, one that Demeritt believes can be taken from the work of Bruno Latour and Donna Haraway, where he finds "a new language to describe nature as both a real actor in human history and as a socially constructed object of these histories" (1994b:179). Demeritt claims to show that Cronon's treatment of ecology as not simply a metaphor but an objective account of first nature, illustrates the dangers Haraway finds in naïve realism. Yet, as Demeritt notes also (1994b:181), Haraway is equally harsh about naïve relativism, dismissing both realism and relativism as "god-tricks" (1991:191).

To abandon Truth with a capital "T" still leaves one with the truth claims of "partial perspectives" to be evaluated on the basis of "shared conversations in epistemology". Taking up the invitation implicit in the "cyborg vision", we can explore further a shared conversation between Marx and Cronon about the nature of the colonial American economy. We might talk about the knowledge they articulate and not only about the different situations from which they speak.

7. There are, of course, alternatives to both Cronon and Marx. Two recent studies of the transformation of the colonial and postcolonial agrarian of New England illustrate the same issues about the interplay between norms and narratives. Merchant (1989) emphasizes the relationship between changing ideas about the place of women in nature, on one hand, and changing systems of property relations on the other. Proletarianization, for Merchant, is a response to the inherent contradictions of this new ideological and legal order. In contrast to the socialist feminism of Merchant, Rothenberg (1992) advocates on behalf of the productivity gains achievable under a market economy. Merchant sees a better future in the supercession of "[p]atriarchy, capitalism, and the domination of nature" (1989:270), whereas Rothenberg holds up the success of capitalist agriculture in postcolonial New England as a positive example of the benefits of market relations, an example, she is happy to find, many formerly socialist countries now following.

8. Since I am critical of what I see as the central normative concerns in Worster's work, I should immediately add that I think his politics lead him more frequently to overstatement than misstatement, although examples of the latter can be found. Furthermore, not all his work is consistent with what might be termed his central line of reasoning. He has expressed doubts himself about his ecological model (1993b) and has developed a much more nuanced argument about the role of culture in some places (see, especially, 1992d).

9. I owe this observation to Bill Cronon.

10. Rose (1991:120), in reviewing The Condition of Postmodernity, criticizes Harvey's "constant parenthetic incantation of 'and women, blacks and other oppressed groups.' " Examples of this inadequate parenthetical political correctness abound in Philo and Kearns (1992).

11. Now, however, Limerick seems less confident about the possibility of regional identities and shared regional pasts serving as a sort of social glue: "Ten years ago, by sheer will, I was able to see in region a form of loyalty and identification that could cross over the barriers of race, ethnicity, gender, and, most astonishing, class. Now I 
strain to see even the outlines of that vision of union through region, or through anything else" (1996:103-04).

\section{References}

Aron, S. 1994. Lessons in Conquest: Towards a Greater Western History. Pacific Historical Review 63:125-47.

Benhabib, S. 1986. Critique, Norm, and Utopia: A Study of the Foundations of Critical Theory. New York: Columbia University Press.

- 1992. Situating the Self: Gender, Community and Postmodernism in Contemporary Ethics. New York: Routledge.

Berkhofer, R. 1971. The Political Context of a New Indian History. Pacific Historical Review 49:357-82.

Bogue, A. G. 1994. An Agricultural Empire. In The Oxford History of the American West, ed. C. A. Milner II, C. A. O'Connor, and M. Sandweiss, pp. 275-313. Oxford: Oxford University Press.

Corbridge, S. 1993. Marxisms, Modernities and Moralities: Development Praxis and the Claims of Distant Strangers. Environment and Planning D: Society and Space 11:449-72.

Cronon, W. 1983. Changes in the Land: Indians, Colonists, and the Ecology of New England. New York: Hill and Wang.

. 1990. Modes of Prophecy and Production: Placing Nature in History. Joumal of American History 76:1122-31.

. 1990-1991. Landscape and Home: Environmental Traditions in Wisconsin. Wisconsin Magazine of History 74:83-105.

1991a. Nature's Metropolis: Chicago and the Great West. New York: W. W. Norton \& Co.

- 1992a. Foreword. In Land Use, Environment, and Social Change: The Shaping of Island County, Washington, 2nd ed., ed. R. White, pp. xi-xvi. Seattle: University of Washington Press.

. 1992b. Kennecott Journey: Paths out of Town. In Under an Open Sky: Rethinking America's Western Past, ed. W. Cronon, G. Miles, and J. Gitlin, pp. 28-52. New York: W. W. Norton \& Co.

- 1992c. A Place for Stories: Nature, History, and Narrative. Journal of American History 78:1347-76.

. 1992d. Telling Tales on Canvas: Landscapes of Frontier Change. In Discovered Lands, Invented Pasts: Transforming Visions of the American West, ed. J. D. Prown, pp. 36-87. New Haven: Yale University Press.

. 1994a. On Totalization and Turgidity. Antipode 26:166-76.

. 1994b. Cutting Loose or Running Aground? Journal of Historical Geography 20:38-43.

1995a. Introduction: In Search of Nature. In Uncommon Ground: Toward Reinventing Nature, ed. W. Cronon, pp. 23-56. New York: W. W. Norton \& Co.

. 1995b. The Trouble with Wilderness; or, Getting Back to the Wrong Nature. In Uncommon Ground: Toward Reinventing Nature, ed. W. Cronon, pp. 69-90. New York: W. W. Norton \& Co.

Cronon, W.; Miles, G.; and Gitlin, J. 1992. Becoming West: Toward a New Meaning for Western History. In Under an Open Sky: Rethinking America's Western Past, ed. W. Cronon, G. Miles, and J. Gitlin, pp. 3-27. New York: W. W. Norton \& Co.

Cronon, W., and White, R. 1986. Indians in the Land. American Heritage 37/5:18-25.

Cutler, A.; Hindess, B.; Hirst, P.; and Hussain, A. 1978. Marx's "Capital" and Capitalism Today, vol. 2. London: Routledge \& Kegan Paul.

Demeritt, D. 1994a. Ecology, Objectivity and Critique in Writings on Nature and Human Societies. Journal of Historical Geography 20:22-37.

- 1994b. The Nature of Metaphors in Cultural Geography and Environmental History. Progress in Human Geography 18:163-85.

Engels, F. 1993[1880]. Socialism: Utopian and Scientific. London: Bookmarks.

Graham, J. 1990. Theory and Essentialism in Marxist Geography. Antipode 22:53-66.

Gulliford, A. 1992. Exhibition Review. The West as America: Reinterpreting Images of the Frontier, 1820-1920, National Museum of American Art, Smithsonian Institution, Washington. Journal of American History 79:199-208.

Haraway, D. 1991. Simians, Cyborgs, and Women: The Reinvention of Nature. London: Routledge.

Harris, C. 1994. From Turner and Von Thünen to Marx and Leopold. Antipode 26:122-25.

Harvey, D. 1996. Justice, Nature and the Geography of Difference. Oxford: Blackwell.

Hawthorn, G. 1991. Plausible Worlds: Possibility and Understanding in History and the Social Sciences. Cambridge: Cambridge University Press.

Hirst, P. 1990. An Answer to Relativism. New Formations 10:13-24.

Holthaus, G.; Limerick, P. N.; and Wilkinson, C. F. 1991. Introduction. In A Society to Match the Scenery: Personal Visions of the Future of the American West, ed. G. Holthaus, P. N. Limerick, C. F. Wilkinson, and E. S. Munson, pp. 3-10. Boulder: University Press of Colorado.

Horkheimer, M., and Adorno, T. W. 1979 [1947]. The Dialectic of Enlightenment. London: Verso.

Hughes, R. 1994. Culture of Complaint: The Fraying of America. London: HarperCollins.

Jackson, R. H. 1981. Land Use in America. London: Edward Arnold.

Jones, E. 1988. Growth Recurring: Economic Change in World History. Oxford: Clarendon Press.

Kay, J. 1989. Western Women's History. Journal of Historical Geography 15:302-05. 
1990. The Future of Historical Geography in the United States. Annals of the Association of American Geographers 80:618-21.

. 1991. Landscapes of Women and Men: Rethinking the Regional Historical Geography of the United States and Canada. Journal of Historical Geography 17:435-52.

Kearns, G. 1984a. Closed Space and Political Practice: Halford Mackinder and Frederick Jackson Turner. Environment and Planning D: Society and Space 2:23-34.

. 1984b. Making Space for Marx. Journal of Historical Geography 10:411-17.

Limerick, P. N. 1985. Desert Passages: Encounters with the American Deserts. Albuquerque: University of New Mexico Press.

. 1987. The Legacy of Conquest: The Unbroken Past of the American West. New York: W. W. Norton $\&$ Co.

- 1991a. The Trail to Santa Fe: The Unleashing of the Western Public Intellectual. In Trails: Toward a New Western History, ed. P. N. Limerick, C. A. Milner II, and C. E. Rankin, pp. 59-77. Lawrence: University of Kansas Press.

- 1991b. Persistent Traits and the Persistent Historian: the American Frontier and Ray Allen Billington. In Writing Western History: Essays on Major Western Historians, ed. R. W. Etulain, pp. 277-310. Albuquerque: University of New Mexico Press.

- 1991c. What on Earth Is the New Western History? In Trails: Toward a New Western History, ed. P. N. Limerick, C. A. Milner II, and C. E. Rankin, pp. 81-88. Lawrence: University of Kansas Press.

- 1991d. Progress or Decline? Judging the History of Western Expansion. In A Society to Match the Scenery: Personal Visions of the Future of the American West, ed. G. Holthaus, P. N. Limerick, C. F. Wilkinson, and E. S. Munson, pp. 43-50. Boulder: University Press of Colorado.

- 1992a. The Multicultural Islands. American Historical Review 97:121-35.

- 1992b. Second Views and Second Thoughts: Mark Klett and the Re-Exploration of the American West. In Revealing Territory: Photographs of the Southwest by Mark Klett, M. Klett, pp. 7-110. Albuquerque: University of New Mexico Press. . 1992c. The Case of the Premature Departure: The Trans-Mississippi West and American History Textbooks. Journal of American History 78:1380-94.

-. 1992d. Making the Most of Words: Verbal Activity and Western America. In Under an Open Sky: Rethinking America's Western Past, ed. W. Cronon, G. Miles, and J. Gitlin, pp. 167-84. New York: W. W. Norton \& Co.

- 1992e. Disorientation and Reorientation: The American Landscape Discovered from the West. Journal of American History 78:1021-49. 1993a. Dancing with Professors: The Trouble with Academic Prose. New York Times Book Review, October 31:23-24.

- 1993b. Precedents to Wisdom. Montana: The Magazine of Western History 43/4:63-66.

. 1994a. The Adventures of the Frontier in the Twentieth Century. In The Frontier in American Culture, ed. J. R. Grossman, pp. 67-102. Berkeley: University of California Press.

- 1994b. Haunted by Rhyolite: Learning from the Landscape of Failure. In The Big Empty: Essays on Western Landscapes as Narrative, ed. L. Engel, pp. 27-47. Albuquerque: University of New Mexico Press.

- 1996. Region and Reason. In All Over the Map: Rethinking American Regions, E. L. Ayers, P. N. Limerick, S. Nissenbaum, P. S. Onuf, pp. 83-104. Baltimore: Johns Hopkins University Press.

Limerick, P.; Milner, C. A.; and Rankin, C. E. 1991. Preface. In Trails: Toward a New Western History, ed. P. N. Limerick, C. A. Milner II, and C. E. Rankin, pp. ix-xv. Lawrence: University of Kansas Press.

Lindstrom, D. and Sharpless, J. 1978. Urban Growth and Economic Structure in Antebellum America. Research in Economic History 3:161-216.

Marx, K. 1974a[1894]. Capital: A Critique of Political Economy, vol. 3. Moscow: Progress Publishers. . 1974b[1874-75]. Conspectus of Bakunin's "Statism and Anarchy." In The First International and After, K. Marx, pp. 333-38. Harmondsworth, U.K.: Penguin Books.

—_. 1975[1844]. Economic and Philosophical Manuscripts. In Early Writings, K. Marx, pp. 279-400. Harmondsworth, U.K.: Penguin Books.

- 1976[1867]. Capital: A Critique of Political Economy, vol. 1. Harmondsworth, U.K.: Penguin Books.

McWilliams, C. 1971. Factories in the Field: The Story of Migratory Farm Labor in California. Santa Barbara, CA: Peregrine.

Meinig, D.W. 1986. The Shaping of America: A Geographical Perspective on 500 Years of History, vol. 1: Atlantic America, 1492-1800. New Haven, CT: Yale University Press.

- 1993. The Shaping of America: A Geographical Perspective on 500 years of History, vol. 2: Continental America 1800-1867. New Haven, CT: Yale University Press.

Merchant, C. 1989. Ecological Revolutions: Nature, Gender, and Science in New England. Chapel Hill: University of North Carolina Press.

— 1990. Gender and Environmental History. Journal of American History 76:1117-21.

- 1994. William Cronon's "Nature's Metropolis." Antipode 26:135-40.

Morris, P. 1994. Where Is the American West? Creating a Base Map for a New Regional History. Paper 
presented at the Association of American Geographers Annual Meeting, San Francisco.

Mouffe, C. 1993. The Return of the Political. London: Verso.

Nash, G. B.; Crabtree, C.; and Dunn, R. E. 1997. History on Trial: Culture Wars and the Teaching of the Past. New York: A. A. Knopf.

Nostrand, R. L. 1992. The Hispano Homeland. Norman: University of Oklahoma Press.

Novick, P. 1988. The Noble Dream: The "Objectivity" Question and the American Historical Profession. Cambridge: Cambridge University Press.

Page, B., and Walker, R. 1994. "Nature's Metropolis": The ghost dance of Christaller and von Thünen. Antipode 26:152-62.

Philo, C., and Kearns, G. 1992. Culture, History, Capital: A Critical Introduction to the Selling of Places. In Selling Places: The City as Cultural Capital, Past and Present, pp. 1-32. London: Pergamon.

Pisani, D. 1992. To Reclaim a Divided West: Water, Law, and Public Policy, 1848-1902. Albuquerque: University of New Mexico Press.

Pudup, M. B. 1994. Trading Places. Antipode 26:116-21.

Rawls, J. 1972. A Theory of Justice. Oxford: Oxford University Press.

Rose, G. 1991. Book Review: D. Harvey, Condition of Postmodernity, and E. Soja, Postmodern Geographies. Journal of Historical Geography 17:118-21.

Rothenberg, W. B. 1992. From Market-Places to a Market Economy: The Transformation of Rural Massachusetts, 1750-1850. Chicago: University of Chicago Press.

Rudnik, L. 1987. Re-naming the Land: Anglo Expatriate Women in the Southwest. In The Desert Is No Lady: Southwestern Landscapes in Women's Writing and Art, ed. V. Norwood and J. Monk, pp. 10-26. New Haven: Yale University Press.

Sauer, C. 1956. The Agency of Man on Earth. In Man's Role in Changing the Face of the Earth, ed. W. I. Thomas, pp. 49-69. Chicago: University of Chicago Press.

Saunders, R. H., and Marston, S. A. 1994. Review of William Cronon's Nature's Metropolis. Antipode 26:126-29

Scott, J. 1988. Gender and the Politics of History. New York: Columbia University Press.

Shoemaker, N. 1996. Regions as Categories of Analysis. Perspectives. American Historical Association Newsletter 34/6: 7-10.

Slotkin, R. 1992. Gunfighter Nation: The Myth of the Frontier in Twentieth-Century America. New York: HarperCollins, Harper Perennial.

Smith, D. 1994. Geography and Social Justice. Oxford: Blackwell.

Stegner, W. 1945. One Nation. Boston: Houghton Mifflin.

Szasz, F. M., and Szasz, M. C. 1994. Religion and Spirituality. In The Oxford History of the American West, ed. C. A. Milner II, C. A. O'Connor, and M.
Sandweiss, pp. 359-91. Oxford: Oxford University Press.

Thompson, E. P. 1968. The Making of the English Working Class, rev. ed. Harmondsworth, U.K.: Penguin.

Thrift, N. 1994. Taking Aim at the Heart of the Region. In Human Geography: Society, Space and Social Science, ed. D. Gregory, R. Martin, and G. Smith, pp. 200-31. London: Macmillan.

Tribe, K. 1981. Genealogies of Capitalism. London: Macmillan.

Truettner, W., and Nemerov, A. 1992. What You See Is Not Necessarily What You Get: New Meaning in Images of the Old West. Montana: The Magazine of Western History 42/3:70-76.

Walton, J. 1992. Western Times and Water Wars: State, Culture, and Rebellion in Califormia. Berkeley: University of California Press.

White, R. 1978. The Winning of the West: The Expansion of the Western Sioux in the Eighteenth and Nineteenth Centuries. Journal of American History 65:319-43.

- 1980. Land Use, Environment, and Social Change: The Shaping of Island County, Washington. Seattle: University of Washington Press.

- 1983. The Roots of Dependency: Subsistence, Environment, and Social Change among the Choctaws, Pawnees, and Navajos. Lincoln: University of Nebraska Press.

- 1985. American Environmental History: The Development of a New Historical Field. Pacific Historical Review 54:297-335.

—. 1988. Frederick Jackson Turner. In Historians of the American Frontier, ed. J. R. Wunder, pp. 660-81. New York: Greenwood Press.

- 1990a. Environmental History, Ecology, and Meaning. Journal of American History 76:1111-16. - 1991a. The Middle Ground: Indians, Empires, and Republics in the Great Lakes Region, 1650-1815. Cambridge: Cambridge University Press.

1991b. "It's Your Misfortune and None of My Own": A New History of the American West. Norman: University of Oklahoma Press.

- 1991c. Trashing the Trails. In Trails: Toward a New Western History, ed. P. N. Limerick, C. A. Milner, and C. E. Rankin, pp. 26-39. Lawrence: University Press of Kansas.

-. 1992a. Preface to the 1992 Edition. In Land Use, Environment, and Social Change: The Shaping of Island County, Washington, 2nd ed., R. White, pp. xvii-xix. Seattle: University of Washington Press.

. 1992b. Discovering Nature in North America. Journal of American History 79:874-91.

. 1992c. "Far West. See also Frontier": The

"New Western History," Textbooks, and the U.S. History Survey Course. Perspectives. American Historical Association Newsletter 30/6: 1,10-12. 
.1994a. Animals and Enterprise. In The Oxford History of the American West, ed. C. A. Milner II, C. A. O'Connor, and M. Sandweiss, pp. 237-73. Oxford: Oxford University Press.

. 1994b. Frederick Jackson Turner and Buffalo Bill. In The Frontier in American Culture, ed. J. R. Grossman, pp. 7-66. Berkeley: University of California Press.

1995. "Are You an Environmentalist or Do You Work for a Living?": Work and Nature. In Uncommon Ground: Toward Reinventing Nature, ed. W. Cronon, pp. 171-85. New York: W. W. Norton \& Co.

Willems-Braun, B. 1997. Buried Epistemologies: The Politics of Nature in (Post)Colonial British Columbia. Annals of the Association of American Geographers 87:3-31.

Williams, M. 1994. The Relations of Environmental History and Historical Geography. Journal of Historical Geography 20:3-21.

Wishart, D. 1994. An Unspeakable Sadness: The Dispossession of the Nebraska Indians. Lincoln: University of Nebraska Press.

- 1997. The Selectivity of Historical Presentation. Journal of Historical Geography 23:111-18.

Wittfogel, K. 1957. Oriental Despotism: A Comparative Study of Total Power. New Haven, CT: Yale University Press.

Wolff, R. D., and Resnick, R. S. 1987. Economics: Marxian vs. Neoclassical. Baltimore: Johns Hopkins University Press.

Worster, D. 1977. Nature's Economy: A History of Ecological Ideas. Sierra Club Books, Cambridge: Cambridge University Press, 1985.

-1979. Dust Bowl: The Southern Plains in the 1930s. Oxford: Oxford University Press.

. 1985. Rivers of Empire: Water, Aridity, and the Growth of the American West. New York: Random House, Pantheon Books; Oxford: Oxford University Press, 1992.

. 1990a. Transformations of the Earth: Toward an Agroecological Perspective in History. Journal of American History 76:1087-06. 1990b. Seeing Beyond Culture. Journal of American History 76:1142-47.

1991. Beyond the Agrarian Myth. In Trails: Toward a New Western History, ed. P. N. Limerick, C. Rankin, and C. A. Milner II, pp. 3-25. Lawrence: University of Kansas Press.

1992a. Cowboy Ecology. In Under Western Skies: Nature and History in the American West, D. Worster, pp. 34-52. Oxford: Oxford University Press.

- 1992b. New West, True West. In Under Western Skies: Nature and History in the American West, D. Worster, pp. 19-33. Oxford: Oxford University Press.

- 1992c. A Country without Secrets. In Under Western Skies: Nature and History in the American West, D. Worster, pp. 238-54. Oxford: Oxford University Press.

- 1992d. The Black Hills: Sacred or Profane? In Under Western Skies: Nature and History in the American West, D. Worster, pp. 106-53. Oxford: Oxford University Press.

- 1993a. The Nature We Have Lost. In The Wealth of Nature: Environmental History and the Ecological Imagination, D. Worster, pp. 1-18. Oxford: Oxford University Press.

- 1993b. The Ecology of Order and Chaos. In The Wealth of Nature: Environmental History and the Ecological Imagination, D. Worster, pp. 156-70. Oxford: Oxford University Press.

Worster, D.; Armitage, S.; Malone, M. P.; Weber, D. J.; and Limerick, P. N. 1989. The Legacy of Conquest by Patricia Nelson Limerick: a Panel of Appraisal. Western Historical Quarterly 20:303-22.

Yeo, S. 1980. State and Anti-State: Reflections on Social Forms and Struggles from 1850. In Capitalism, State Formation and Marxist Theory, ed. P. Corrigan, pp. 111-41. London: Quartet Books. 